NATIONAL LABORATORY

\title{
Metallurgical Evaluation of Grit Blasted Versus Non-Grit Blasted Iridium Alloy Clad Vent Set Cup Surfaces
}

February 2010

Prepared by

George B. Ulrich

Hu F. Longmire

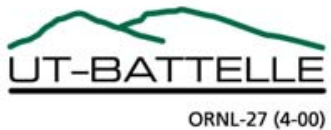




\section{DOCUMENT AVAILABILITY}

Reports produced after January 1, 1996, are generally available free via the U.S. Department of Energy (DOE) Information Bridge.

Web site http://www.osti.gov/bridge

Reports produced before January 1, 1996, may be purchased by members of the public from the following source.

National Technical Information Service

5285 Port Royal Road

Springfield, VA 22161

Telephone 703-605-6000 (1-800-553-6847)

TDD 703-487-4639

Fax 703-605-6900

E-mail info@ntis.gov

Web site http://www.ntis.gov/support/ordernowabout.htm

Reports are available to DOE employees, DOE contractors, Energy Technology Data Exchange (ETDE) representatives, and International Nuclear Information System (INIS) representatives from the following source.

Office of Scientific and Technical Information

P.O. Box 62

Oak Ridge, TN 37831

Telephone 865-576-8401

Fax 865-576-5728

E-mail reports@osti.gov

Web site http://www.osti.gov/contact.html

This report was prepared as an account of work sponsored by an agency of the United States Government. Neither the United States Government nor any agency thereof, nor any of their employees, makes any warranty, express or implied, or assumes any legal liability or responsibility for the accuracy, completeness, or usefulness of any information, apparatus, product, or process disclosed, or represents that its use would not infringe privately owned rights. Reference herein to any specific commercial product, process, or service by trade name, trademark, manufacturer, or otherwise, does not necessarily constitute or imply its endorsement, recommendation, or favoring by the United States Government or any agency thereof. The views and opinions of authors expressed herein do not necessarily state or reflect those of the United States Government or any agency thereof. 
Materials Science and Technology Division

\section{METALLURGICAL EVALUATION OF GRIT BLASTED VERSUS NON-GRIT BLASTED IRIDIUM ALLOY CLAD VENT SET CUP SURFACES}

George B. Ulrich and Hu F. Longmire

Date Published: February 2010

Prepared by

OAK RIDGE NATIONAL LABORATORY

Oak Ridge, Tennessee 37831-6283

managed by

UT-BATTELLE, LLC

for the

U.S. DEPARTMENT OF ENERGY

under contract DE-AC05-00OR22725 



\section{CONTENTS}

Page

LIST OF FIGURES

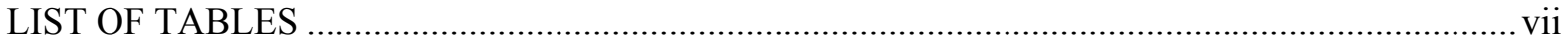

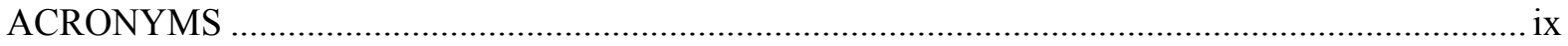

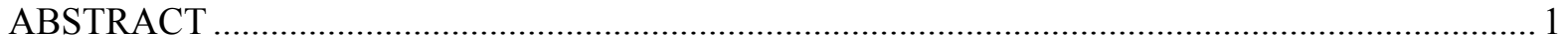

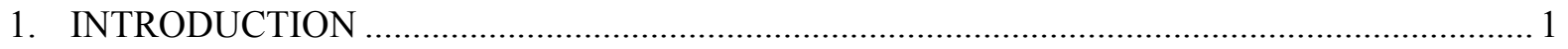

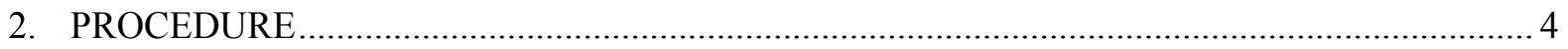

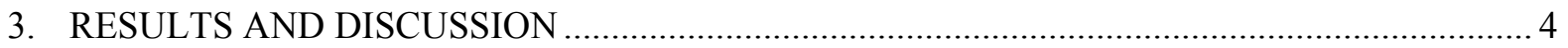

3.1 RECRYSTALLIZED AND GRIT BLASTED CONDITION …......................................... 4

3.2 RECRYSTALLIZED, GRIT BLASTED, AIR BURN-OFF, AND

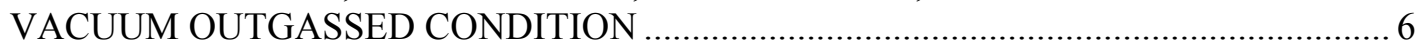

3.3 RECRYSTALLIZED, GRIT BLASTED, AIR BURN-OFF, VACUUM OUTGASSED AND SUBSEQUENT HEAT TREATMENT CONDITIONS ..................... 9

3.4 ANOMALOUS CLAMPED (DURING DEBURRING) AREAS OF USED WITNESS SPECIMENS SUBSEQUENTLY GIVEN VARIOUS HEAT TREATMENTS 14

3.5 COMPARISON OF CVS CUP PRODUCTION METALLURGICAL

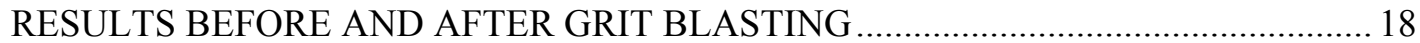

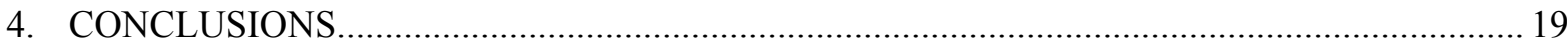

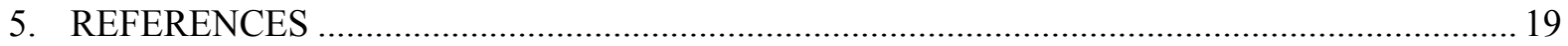





\section{LIST OF FIGURES}

Figure $\quad$ Page

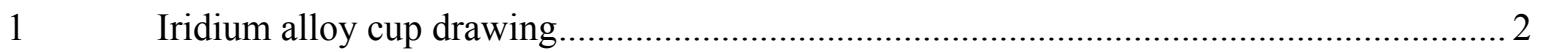

2 Iridium alloy cup CVS manufacturing process/procedure flow ................................... 3

3 Photomicrograph at 500X magnification showing typical cold worked surface from grit blasting on outside of iridium alloy cup ............................................................... 5

4 Photomicrograph at 500X magnification showing typical non-grit blasted (inside)

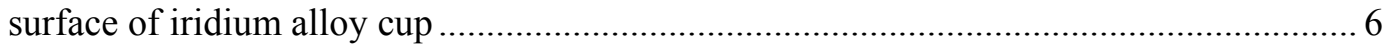

5 Photomicrograph at 100X magnification showing fine-grained outside (upper) surface vs. the overall grain size, plus the apparent tendency to have fine grains at the inside (lower) surface for an iridium alloy cup sample in the recrystallized, grit blasted, air burn-off, and vacuum outgassed condition ....

Photomicrograph at 500X magnification showing fine-grained outside (upper)

surface vs. the overall grain size for an iridium alloy cup sample in the recrystallized, grit blasted, air burn-off, and vacuum outgassed condition

Photomicrograph at 100X magnification showing fine-grained outside (upper)

surface vs. the overall grain size for a used witness specimen (recrystallized, grit blasted, air burn-off, and vacuum outgassed) and subsequently final heat treated at $1375^{\circ} \mathrm{C} / 1 \mathrm{~h}$

Photomicrograph at 500X magnification showing fine-grained outside (upper) surface vs. the overall grain size for a used witness specimen (recrystallized, grit blasted, air burn-off, and vacuum outgassed) and subsequently final heat treated at $1375^{\circ} \mathrm{C} / 1 \mathrm{~h}$.

Photomicrograph at 100X magnification showing fine-grained outside (upper) surface vs. the overall grain size for a used witness specimen (recrystallized, grit blasted, air burn-off, and vacuum outgassed) and subsequently final heat treated at $1500^{\circ} \mathrm{C} / 1 \mathrm{~h}$.....

10 Photomicrograph at $100 \mathrm{X}$ magnification showing a fairly uniform grain size on the outside (upper), inside (lower), and overall for a used witness specimen (recrystallized, grit blasted, air burn-off, and vacuum outgassed) and subsequently final heat treated at $1500^{\circ} \mathrm{C} / 1 \mathrm{~h}$

11 Photomicrograph at 100X magnification showing a fairly uniform grain size on the outside (upper), inside (lower), and overall for a used witness specimen (recrystallized, grit blasted, air burn-off, and vacuum outgassed) and subsequently final heat treated at $1500^{\circ} \mathrm{C} / 70 \mathrm{~h}$

12 Photomicrograph at 100X magnification showing a fairly uniform grain size on the outside (upper), inside (lower), and overall for a used witness specimen (recrystallized, grit blasted, air burn-off, and vacuum outgassed) and subsequently final heat treated at $1900^{\circ} \mathrm{C} / 1 \mathrm{~min}$

13 Photomicrograph at $100 \mathrm{X}$ magnification showing a fairly uniform grain size on the outside (upper), inside (lower), and overall for a used witness specimen (recrystallized, grit blasted, air burn-off, and vacuum outgassed) and subsequently final heat treated at $1900^{\circ} \mathrm{C} / 2 \mathrm{~h}$ 
14 Photomicrograph at $100 \mathrm{X}$ magnification showing a typical clamped area with deformation and some grain boundary separation on the outside (upper) and inside (lower) surfaces of a used witness specimen (recrystallized, grit blasted, clamped, air burn-off, and vacuum outgassed) - no grain growth

15 Photomicrograph at 200X magnification of the clamped area on the inside (lower) surface of figure 14 clearly showing grain deformation and some grain boundary separation.

16 Photomicrograph at $100 \mathrm{X}$ magnification showing the clamped area of the sample heat treated at $1375^{\circ} \mathrm{C} / 1 \mathrm{~h}$ after recrystallization, grit blast, clamping, air burn-off, and vacuum outgas. Some grain boundary separation is evident on the outside (upper) surface, but no grain growth has occurred.

17 Photomicrograph at $100 \mathrm{X}$ magnification showing the clamped area of the sample heat treated at $1500^{\circ} \mathrm{C} / 1 \mathrm{~h}$ after recrystallization, grit blast, clamping, air burn-off, and vacuum outgas. Reduced thickness and grain boundary separation are evident as well as grain growth

18 Photomicrograph at 100X magnification showing the clamped area of the sample heat treated at $1500^{\circ} \mathrm{C} / 70 \mathrm{~h}$ after recrystallization, grit blasted, clamping, air burn-off, and vacuum outgas. Reduced thickness and some grain boundary separation are evident as well as enlarged grains. Compare to figure 11 for abnormal grain growth Photomicrograph at 100X magnification showing the clamped area of the sample heat treated at $1900^{\circ} \mathrm{C} / 2 \mathrm{~h}$ after recrystallization, grit blast, clamping, air burn-off, and vacuum outgas. Reduced thickness and some grain boundary (former) separation are evident as well as the single grain in this area. Compare figure 13 for abnormal grain growth 


\section{LIST OF TABLES}

Table

Page

1 Metallurgical Summary for Sample (8 total) in the Recrystallized and Grit Blasted

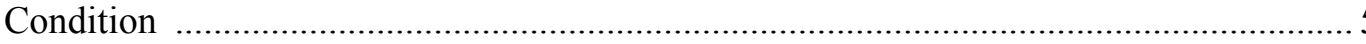

2 Metallurgical Summary for Outside and Inside Surfaces of Samples in the Recrystallized, Grit Blasted, Air Burn-off, and Vacuum Outgassed Condition (Used Witness Specimens - Similar to CVS Assembly)

3 Metallurgical Summary for Overall (Bulk Portion of) Samples in the Recrystallization, Grit Blasted, Air Burn-off, and Vacuum Outgassed Condition (Used Witness Specimens - Similar to CVS Assembly)

$4 \quad$ Metallurgical Summary for the Outside and Inside Surfaces of Samples Given Subsequent Final Heat Treatments after the Recrystallization, Grit Blasted, Air Burn-off, and Vacuum Outgas Operations

5 Metallurgical Summary for Overall (Bulk Portion of) Samples Given Subsequent Final Heat Treatments after the Recrystallization, Grit Blast, Air Burn-off, and Vacuum Outgas Operations

6 Clamping Strain and Number of Grains Through the Thickness in Deformed Regions of Final Heat Treatment (after the Recrystallization, Grit Blast, Air Burnoff, and Vacuum Outgas Operations) Samples....

Metallurgical Summary for Iridium Alloy CVS Cup Production Destructive Test Results for the Years 1999 - 2009 



\section{ACRONYMS}

ASTM American Society for Testing and Materials

CVS Clad Vent Set

EDM electrical discharge machined

h hour

HV Vickers hardness

min minute

ORNL Oak Ridge National Laboratory 



\title{
METALLURGICAL EVALUATION OF GRIT BLASTED VERSUS NON-GRIT BLASTED IRIDIUM ALLOY CLAD VENT SET CUP SURFACES*
}

\author{
George B. Ulrich and Hu F. Longmire
}

\begin{abstract}
Metallurgical evaluations were conducted to determine what, if any, grain size differences exist between grit blasted and non-grit blasted DOP-26 iridium alloy cup surfaces and if grit blasting imparts sufficient compressive cold work to induce abnormal grain growth during subsequent temperature exposures. Metallographic measurements indicated that grit blasting cold worked the outside cup surface to a depth of approximately $19 \mu \mathrm{m}$. Subsequent processing through the air burn-off $\left(635^{\circ} \mathrm{C} / 4 \mathrm{~h}\right)$ and vacuum outgassing $\left(1250^{\circ} \mathrm{C} / 1 \mathrm{~h}\right)$ operations was found to uniformly recrystallize the cold worked surface to produce grains with an average diameter of approximately $8.5 \mu \mathrm{m}$ (American Society for Testing and Materials (ASTM) grain size number 11). Follow-on heat treatments at $1375^{\circ} \mathrm{C}, 1500^{\circ} \mathrm{C}$, and $1900^{\circ} \mathrm{C}$ for durations ranging from 1 min to $70 \mathrm{~h}$ yielded uniform grain sizes and no abnormal grain growth from grit blasting. Abnormal grain growth was noted at the $1500^{\circ} \mathrm{C}$ and $1900^{\circ} \mathrm{C}$ heat treatments in areas of cold work from excessive clamping during sample preparation.
\end{abstract}

\section{INTRODUCTION}

DOP-26 iridium alloy (nominally $0.3 \%$ tungsten, $0.006 \%$ thorium, and $0.005 \%$ aluminum by weight) cups (Fig. 1) are used for primary containment of plutonium-238 dioxide pellets. The encapsulated pellets (fueled Clad Vent Sets) are used in radioisotope power systems usually to power instrumentation for National Aeronautic and Space Administration deep-space missions. The Clad Vent Set (CVS) manufacturing process/procedure flow for cups is shown in Fig. 2. Blanks (52 $\mathrm{mm}$ diameter $\mathrm{x} 0.65 \mathrm{~mm}$ thick) are received in the wrought $\left(80 \%\right.$ reduction after an intermediate $1300^{\circ} \mathrm{C} / 1 \mathrm{~h}$ recrystallization heat treatment $)$ and vacuum stress relieved $\left(900^{\circ} \mathrm{C} / 1 \mathrm{~h}\right)$ condition. The blanks are encapsulated in tantalum and stainless steel then warmformed $\left(925^{\circ} \mathrm{C} / 10 \mathrm{~min}\right.$ preheat $)$ in two deep draw operations. After cup forming the encapsulation materials are chemically removed and the iridium cups are acid cleaned prior to recrystallization at $1375^{\circ} \mathrm{C} / 1 \mathrm{~h}$ in vacuum $\left[\leq 1 \times 10^{-4}\right.$ Torr $\left.]\right)$.

One cup from a heat treat lot (group of cups recrystallized together) is destructively tested (D-tested) for metallurgical and chemical analyses per the Oak Ridge National Laboratory (ORNL) Deep Drawn Iridium Alloy Cups Specification GPHS-M-188, Rev. 8. Each D-test cup is electrical discharge machined (EDM) into 12 samples (cup segments). The samples are deburred by hand to remove the EDM layer prior to additional sample preparation. The D-test cup may be selected any time after the post-deep-draw recrystallization heat treat operation. Many D-test cups are selected for testing after the dye penetrant inspection/polishing operations as shown in Fig. 2, but some are selected after the grit blasting operation depending on production needs/availability.

The grit blasting operation is conducted with tungsten carbide powder procured per ORNL Specification GPHS-M-189, Rev. 6. The powder is sieved to Tyler series -65 mesh $(212 \mu \mathrm{m}) /+150$ mesh $(106 \mu \mathrm{m})$. A dedicated Empire Abrasive Equipment Company (Langhorne, PA) Pro-Finish Model PF-2636 grit blaster is used at a line pressure of $50 \pm 5$ psi for approximately $25 \mathrm{~s}$ with the nozzle approximately 4 " from a cup. One cup at a time is placed in a polyvinyl chloride fixture (T2E139776, Rev. F) for consistent holding and masking.

*Research sponsored by the U.S. Department of Energy, Office of Space and Defense Power Systems, under contract with UTBattelle, LLC. 


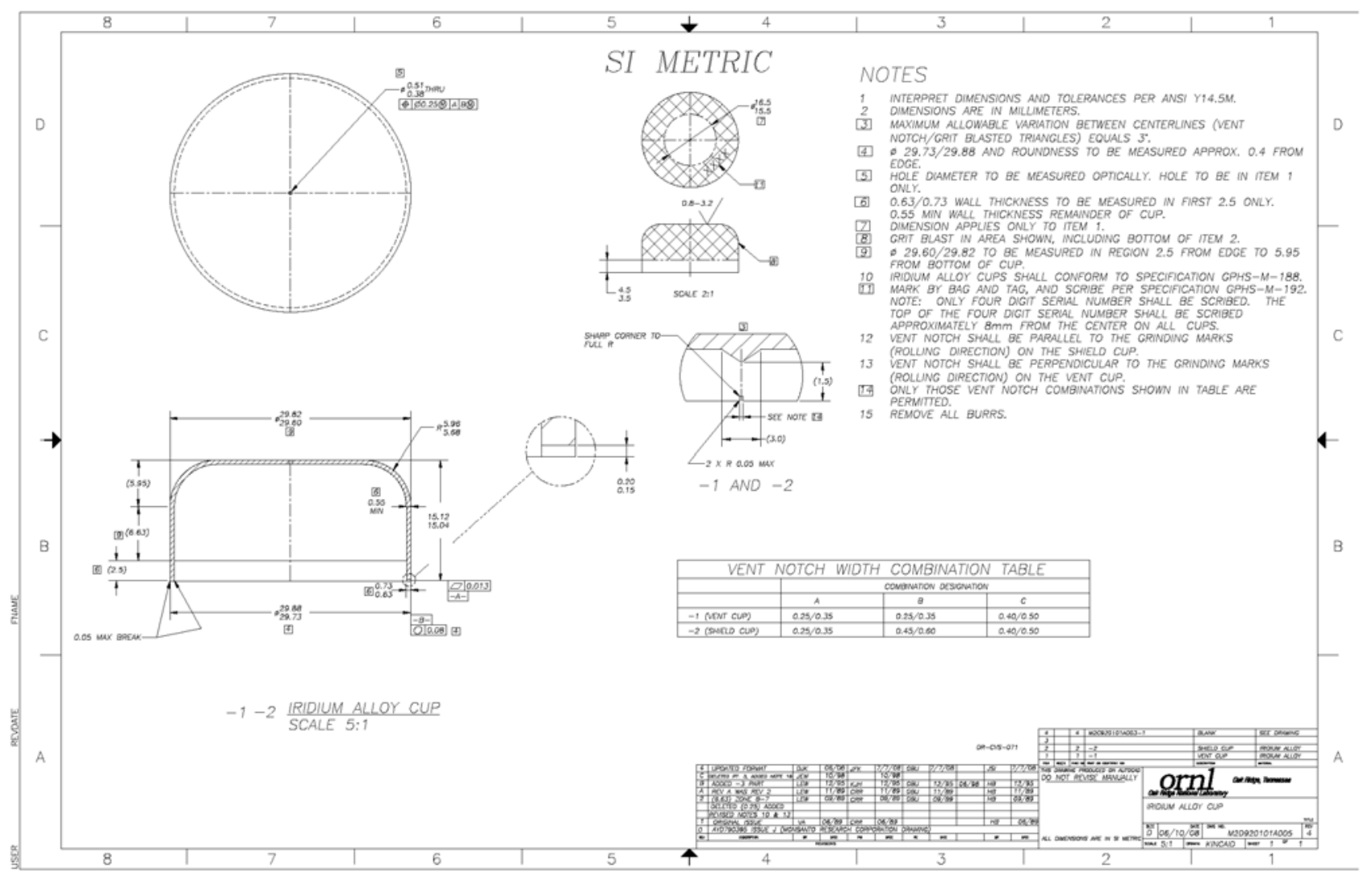

Fig. 1. Iridium alloy cup drawing. 


\begin{tabular}{|c|}
\hline $\begin{array}{l}\text { Receive Blank in wrought \& } \\
\text { stress relieved condition }\end{array}$ \\
\hline $\begin{array}{l}\text { Engrave Blank } \\
\text { GPHS-XF-3624/25 }\end{array}$ \\
\hline $\begin{array}{l}\text { Clean-Ir, Ta, SS } \\
\text { GPHS-Y-005/-007 }\end{array}$ \\
\hline $\begin{array}{l}\text { Weld Blank Assembly } \\
\text { GPHS-K-001 }\end{array}$ \\
\hline $\begin{array}{l}\text { First-form } \\
\text { GPHS-XF-3624/25 }\end{array}$ \\
\hline $\begin{array}{l}\text { Fabricate Mild Steel Cup } \\
\text { GPHS-FABR-7735/7735A }\end{array}$ \\
\hline $\begin{array}{l}\text { Second-form } \\
\text { GPHS-XF-3624/25 }\end{array}$ \\
\hline $\begin{array}{l}\text { Trim } \\
\text { GPHS-XF-3624/25 }\end{array}$ \\
\hline $\begin{array}{l}\text { Acid Strip } \\
\text { GPHS-Y-006 }\end{array}$ \\
\hline $\begin{array}{l}\text { Clean } \\
\text { GPHS-Y-005 }\end{array}$ \\
\hline $\begin{array}{l}\text { Store Archive Rings } \\
\text { GPHS-XF-3624/25 }\end{array}$ \\
\hline $\begin{array}{l}\text { Recrystallize } \\
\text { GPHS-Y-002 }\end{array}$ \\
\hline $\begin{array}{l}\text { Size } \\
\text { GPHS-XF-3624/25 }\end{array}$ \\
\hline $\begin{array}{l}\text { Grind } \\
\text { GPHS-XF-3624/25 }\end{array}$ \\
\hline $\begin{array}{l}\text { Lap } \\
\text { GPHS-XF-3624/25 }\end{array}$ \\
\hline
\end{tabular}

\begin{tabular}{|c|}
\hline $\begin{array}{l}\text { Vent Notch } \\
\text { GPHS-XF-3624/25 }\end{array}$ \\
\hline $\begin{array}{l}\text { Polish } \\
\text { GPHS-XF-3624/25 }\end{array}$ \\
\hline $\begin{array}{l}\text { Penetrant Inspection } \\
\text { GPHS-Y-010 }\end{array}$ \\
\hline $\begin{array}{l}\text { Polish } \\
\text { GPHS-XF-3624/25 }\end{array}$ \\
\hline $\begin{array}{l}\text { Section D-test } \\
\text { GPHS-XF-3624/25A }\end{array}$ \\
\hline $\begin{array}{l}\text { Certify Carbon } \\
\text { GPHS-Y-021 or } \\
\text { MST-MatP-SOG-110 }\end{array}$ \\
\hline $\begin{array}{l}\text { Certify Oxygen } \\
\text { GPHS-Y-022 or } \\
\text { MST-MatP-SOG-111 }\end{array}$ \\
\hline $\begin{array}{l}\text { Certify GDMS } \\
\text { MET-MatP-SOP-79 }\end{array}$ \\
\hline $\begin{array}{l}\text { Certify Metallography } \\
\text { MET-MetL-QA-2 }\end{array}$ \\
\hline $\begin{array}{l}\text { EDM Vent Hole (3624) } \\
\text { GPHS-XF-3624/25 }\end{array}$ \\
\hline $\begin{array}{l}\text { Clean } \\
\text { GPHS-Y-005 }\end{array}$ \\
\hline $\begin{array}{l}\text { WC Grit Impurity Cert. } \\
\text { ACO-SOW-001 }\end{array}$ \\
\hline $\begin{array}{l}\text { Grit Blast } \\
\text { GPHS-XF-3624/25 }\end{array}$ \\
\hline $\begin{array}{l}\text { Flatten } \\
\text { GPHS-XF-3624/25 }\end{array}$ \\
\hline $\begin{array}{l}\text { Engrave Cup (final) } \\
\text { GPHS-XF-3624/25 }\end{array}$ \\
\hline
\end{tabular}

\begin{tabular}{|l|}
\hline $\begin{array}{l}\text { Cup Wt./Fab. Audit } \\
\text { GPHS-XF-3624/25 }\end{array}$ \\
\hline $\begin{array}{l}\text { Dimensional Inspection } \\
\text { GPHS-C-3624/25 }\end{array}$ \\
\hline $\begin{array}{l}\text { Rework-Fab Operations } \\
\text { GPHS-XF-3624/25 }\end{array}$ \\
\hline $\begin{array}{l}\text { Dimensional Inspection } \\
\text { GPHS-C-3624/25 }\end{array}$ \\
\hline $\begin{array}{l}\text { Clean } \\
\text { GPHS-Y-005 }\end{array}$ \\
\hline $\begin{array}{l}\text { Cert. Review } \\
\text { Assign - 9753/9754 }\end{array}$ \\
\hline $\begin{array}{l}\text { Air Burn-Off (witness } \\
\text { specimen or assembly) } \\
\text { GPHS-Y-002 }\end{array}$ \\
\hline $\begin{array}{l}\text { Vacuum Outgas (witness } \\
\text { specimen or assembly) } \\
\text { GPHS-Y-002 }\end{array}$ \\
\hline
\end{tabular}

Fig. 2. Iridium alloy cup CVS manufacturing process/procedure flow. 
The fixture is placed on a rotary table and manually rotated while the grit blast nozzle is manually held and moved to ensure full coverage of the exposed surfaces of the cup. Note: Grit blasting is done on the outer surfaces of the cups for emissivity purposes in use.

\section{PROCEDURE}

A total of eight D-test samples from cup 3625-05-5104 (blank G3-14-4) and nine samples from cup 3625-05-5164 (blank G2-3-7) were metallurgically evaluated in various processing conditions. Cup 3625-05-5104 was processed through the Rework-Fab Operations (see Fig. 2) for re-sizing prior to D-test sectioning while cup 3625-05-5164 was processed through the Engrave Cup (final) operation (Fig. 2) without any rework before sectioning. Each sample was manually deburred after it was EDM from the cup to remove the EDM-affected edges. The samples were then prepared metallographically (mount, grind, polish, and etch) and evaluated for depth of cold work, grain size, and microhardness (Vickers using $1000 \mathrm{~g}$ load - average of three indentations at each location) at the pole, radius, and equator locations per ORNL procedure MET-MetL-QA-2, Rev. 9 as appropriate. Cold worked areas were characterized by visible slip lines near the outer cup surface. These slip lines appeared as wavy slip which was easily distinguished from straight scratch marks that sometimes remained as artifacts of polishing. The microhardness measurements were from the interior or bulk region - not the cold worked surface region.

Four original D-test samples from each of the two grit blasted cups were evaluated at the grit blasted surface for depth of cold work and overall for grain size and microhardness. The cold work depth values consisted of an average of three measurements from a 500X magnification image. Two other D-test samples (from each cup) that had been used as witness specimens for the air burn-off $\left(635^{\circ} \mathrm{C} / 4 \mathrm{~h}\right)$ and vacuum outgas $\left(1250^{\circ} \mathrm{C} / 1 \mathrm{~h}\right)$ operations were evaluated for grain sizes on the grit blasted (outside) and the non-grit blasted (inside) surfaces and overall for grain size and microhardness. (Note: witness specimens are no longer utilized in CVS manufacturing. Witness specimens were extra D-test samples that accompanied finished assemblies through the air burn-off and vacuum outgassing operations.) Additional used witness specimens were given additional vacuum heat treatments at $1375^{\circ} \mathrm{C} / 1 \mathrm{~h}$, $1500^{\circ} \mathrm{C} / 1 \mathrm{~h}, 1500^{\circ} \mathrm{C} / 70 \mathrm{~h}, 1900^{\circ} \mathrm{C} / 1 \mathrm{~min}$, or $1900^{\circ} \mathrm{C} / 2 \mathrm{~h}$ and evaluated for grain sizes on the grit blasted and the non-grit blasted surfaces and overall for grain size and microhardness. Note: The selection of the additional heat treatment temperatures and times was arbitrary.

\section{RESULTS AND DISCUSSION}

\subsection{RECRYSTALLIZED AND GRIT BLASTED CONDITION}

A summary of the combined results for the four original D-test samples from each of the two grit blasted cups (total of 8 samples) are shown in Table 1 . The table includes the combined averages, standard deviations, relative standard deviations (standard deviation $\div$ average $\times 100$ ), maximums, minimums, and ranges by position for all eight samples. The results indicate that the depth of cold work averages about $19 \mu \mathrm{m}$ regardless of position. The depth of cold work minimum and maximum values show the variability inherent in the manual grit blast operation with overall minimum and maximum depths of 11 and $36 \mu \mathrm{m}$, respectively. Figs. 3 and 4 are photomicrographs showing the typical grit blasted (outside) and non-grit blasted (inside) surfaces, respectively. Table 1 shows that the overall (excluding the cold worked surface) grain sizes are uniform - typically near an ASTM grain size number 6. Also the overall microhardness values (Vickers indenter with 1000 gram-force) are fairly consistent with overall minimums and maximums of 231 and $271 \mathrm{HV}$, respectively. The radius position with a 
Table 1. Metallurgical Summary for Samples (8 total) in the Recrystallized and Grit Blasted Condition

\begin{tabular}{|c|c|c|c|c|c|c|c|c|c|}
\hline & \multicolumn{3}{|c|}{$\begin{array}{c}\text { Depth of cold work } \\
\text { @ grit blast edge }(\mu \mathrm{m})\end{array}$} & \multicolumn{3}{|c|}{$\begin{array}{c}\text { Overall ASTM } \\
\text { Grain Size Number }\end{array}$} & \multicolumn{3}{|c|}{$\begin{array}{l}\text { Microhardness } \\
\text { (HV 1000 gf) }\end{array}$} \\
\hline & Pole & Radius & Equator & Pole & Radius & Equator & Pole & Radius & Equator \\
\hline Av & 17 & 21 & 19 & 6.1 & 6.1 & 5.9 & 241 & 258 & 244 \\
\hline $\mathrm{SD}$ & 6 & 5 & 8 & 0.3 & 0.4 & 0.4 & 2 & 7 & 10 \\
\hline RSD (\%) & 35 & 24 & 42 & 5 & 7 & 7 & 1 & 3 & 4 \\
\hline Max & 29 & 31 & 36 & 5.5 & 5.5 & 5.5 & 243 & 271 & 259 \\
\hline Min & 11 & 14 & 12 & 6.5 & 6.5 & 6.5 & 236 & 249 & 231 \\
\hline Range & 18 & 17 & 24 & 1.0 & 1.0 & 1.0 & 7 & 22 & 28 \\
\hline
\end{tabular}

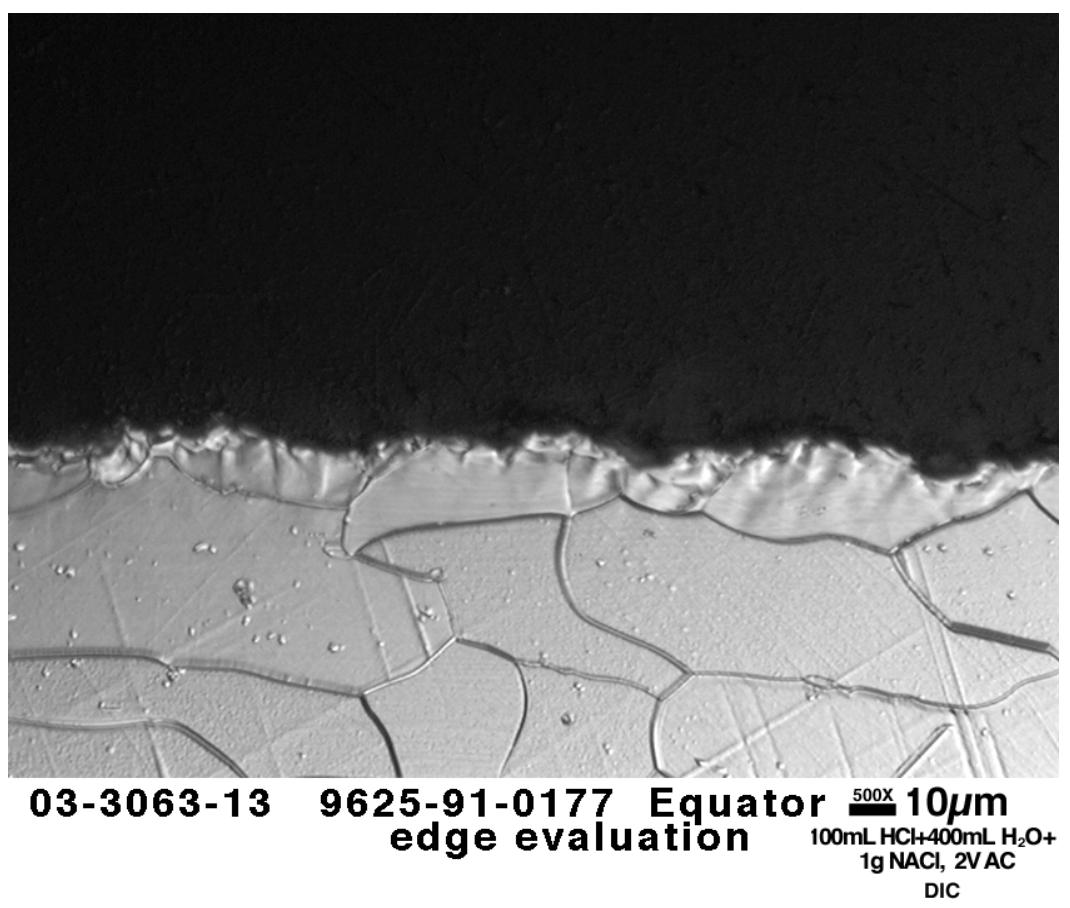

Fig. 3. Photomicrograph at 500X magnification showing typical cold worked surface from grit blasting on outside of iridium alloy cup. 


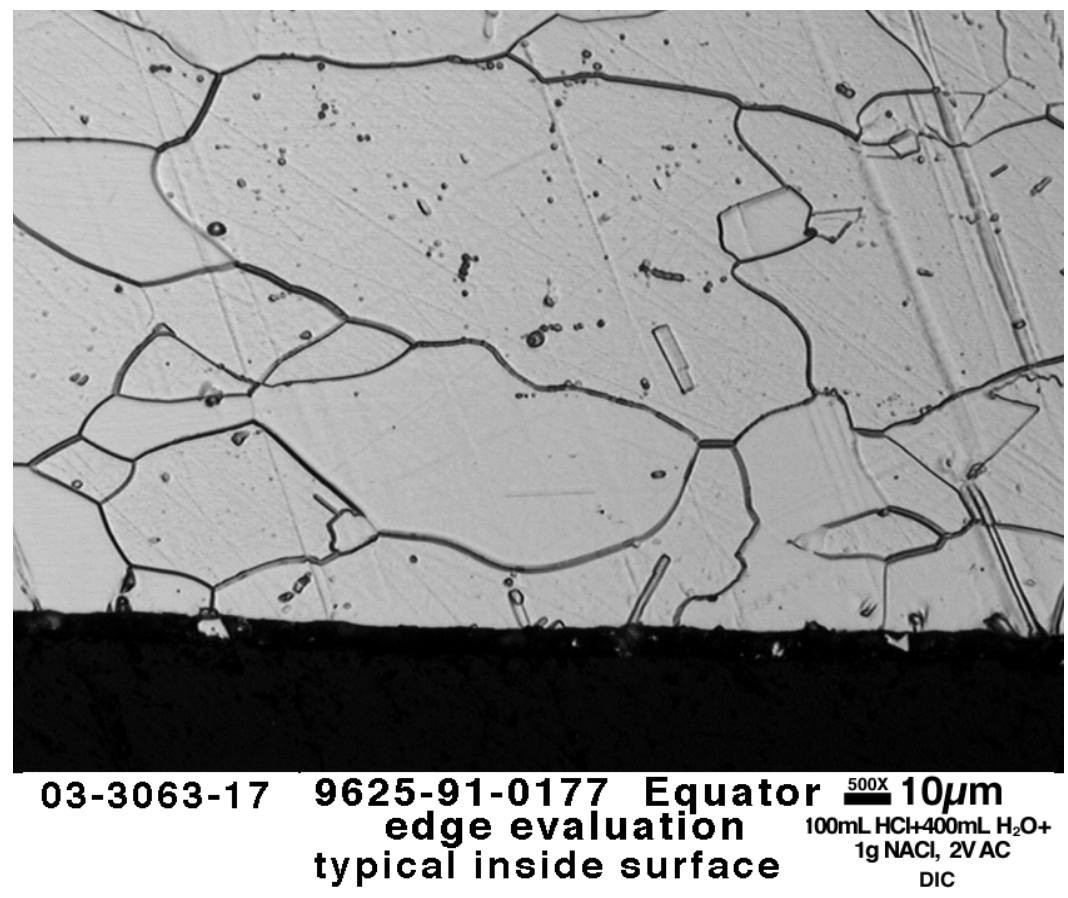

Fig. 4. Photomicrograph at 500X magnification showing typical non-grit blasted (inside) surface of iridium alloy cup.

grand average of $258 \mathrm{HV}$ is slightly elevated from the pole grand average of $241 \mathrm{HV}$ and the equator grand average of 244. This may be explained by the cup cold sizing operation (see Fig. 2 -immediately after the recrystallization operation or part of the final rework) imparting more cold work in the radius than anywhere else.

\subsection{RECRYSTALLIZED GRIT BLASTED, AIR BURN-OFF, AND VACUUM OUTGASSED CONDITION \\ (SAME AS FINISHED CVS ASSEMBLY AND/OR USED WITNESS SPECIMEN)}

A summary of the combined results at the outside and inside surfaces for two used witness specimens (recrystallized, grit blasted, air burn-off, and vacuum outgassed condition which is the same condition of finished CVS assemblies) from both of the grit blasted cups are shown in Table 2. The table includes the combined averages, standard deviations, relative standard deviations, maximums, minimums, and ranges by position and surface (outside grit blasted or inside non-grit blasted) for all four samples. Also Figs. 5 and 6 are photomicrographs showing the typical overall grain structure and the fine-grained outside surface, respectively, for one of these samples. The results show that the outside grit blasted (cold worked) surface is recrystallized by the $1250^{\circ} \mathrm{C} / 1 \mathrm{~h}$ vacuum outgas operation. The outside surface grain size diameter averages about $9 \mu \mathrm{m}$ regardless of position versus about $33 \mu \mathrm{m}$ at the inside surface. These average grain size diameters convert to ASTM grain size numbers of 11 and 7 for the outside and inside surfaces, respectively. Recrystallization and probably some grain growth occurred during the original $1375^{\circ} \mathrm{C} / 1 \mathrm{~h}$ "recrystallization" operation at the inside surfaces (as well as the rest of the cup/sample) while little or no grain growth, only recrystallization, occurred at the grit blasted (cold worked) outside surfaces during the subsequent $1250^{\circ} \mathrm{C} / 1 \mathrm{~h}$ vacuum outgas operation. 
Table 2. Metallurgical Summary for Outside and Inside Surfaces of Samples in the Recrystallized, Grit Blasted, Air Burn-off, and Vacuum Outgassed

Condition (Used Witness Specimens - Similar to CVS Assembly)

\begin{tabular}{lcccccc}
\multicolumn{1}{c}{ Surface } & \multicolumn{2}{c}{ Average Grain Size Diameter $(\boldsymbol{\mu m})$} & \multicolumn{3}{c}{$\begin{array}{c}\text { Approximate ASTM } \\
\text { Grain Size Number }\end{array}$} \\
\hline Outside & Pole & Radius & Equator & Pole & Radius & Equator \\
\hline Av & 8 & 10 & 8 & 11.1 & 10.8 & 10.9 \\
SD & 3 & 4 & 1 & 1.6 & 1.0 & 0.5 \\
RSD (\%) & 38 & 40 & 13 & 14 & 9 & 5 \\
Max & 12 & 15 & 10 & 9.3 & 9.3 & 10.4 \\
Min & 4 & 7 & 7 & 13.0 & 11.5 & 11.6 \\
Range & 8 & 8 & 3 & 3.7 & 2.2 & 1.2 \\
\hline & & & & & & \\
Inside & Pole & Radius & Equator & Pole & Radius & Equator \\
\hline Av & 30 & 32 & 36 & 7.4 & 7.1 & 6.6 \\
SD & 11 & 10 & 4 & 1.2 & 0.9 & 0.2 \\
RSD $(\%)$ & 37 & 31 & 11 & 16 & 13 & 3 \\
Max & 38 & 46 & 40 & 6.5 & 6.1 & 6.4 \\
Min & 16 & 24 & 32 & 9.1 & 8.0 & 6.9 \\
Range & 22 & 22 & 8 & 2.6 & 1.9 & 0.5 \\
\hline
\end{tabular}

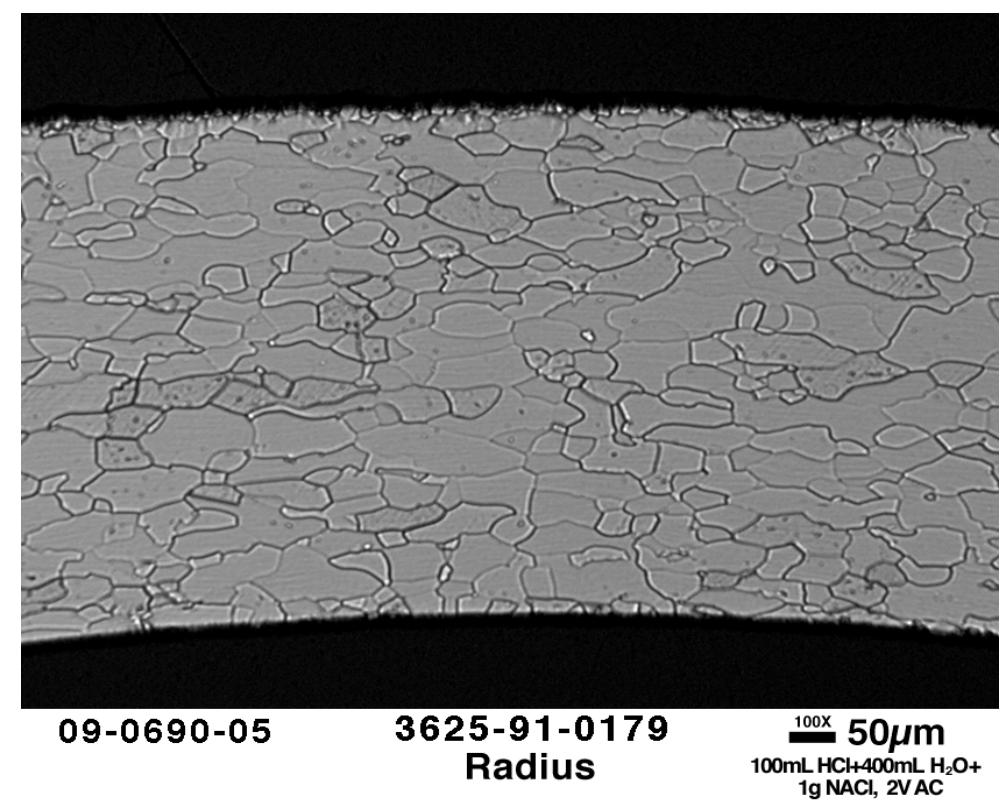

Fig. 5. Photomicrograph at $100 \mathrm{X}$ magnification showing finegrained outside (upper) surface vs. the overall grain size, plus the apparent tendency to have fine grains at the inside (lower) surface for an iridium alloy cup sample in the recrystallized, grit blasted, air burn-off, and vacuum outgassed condition. 


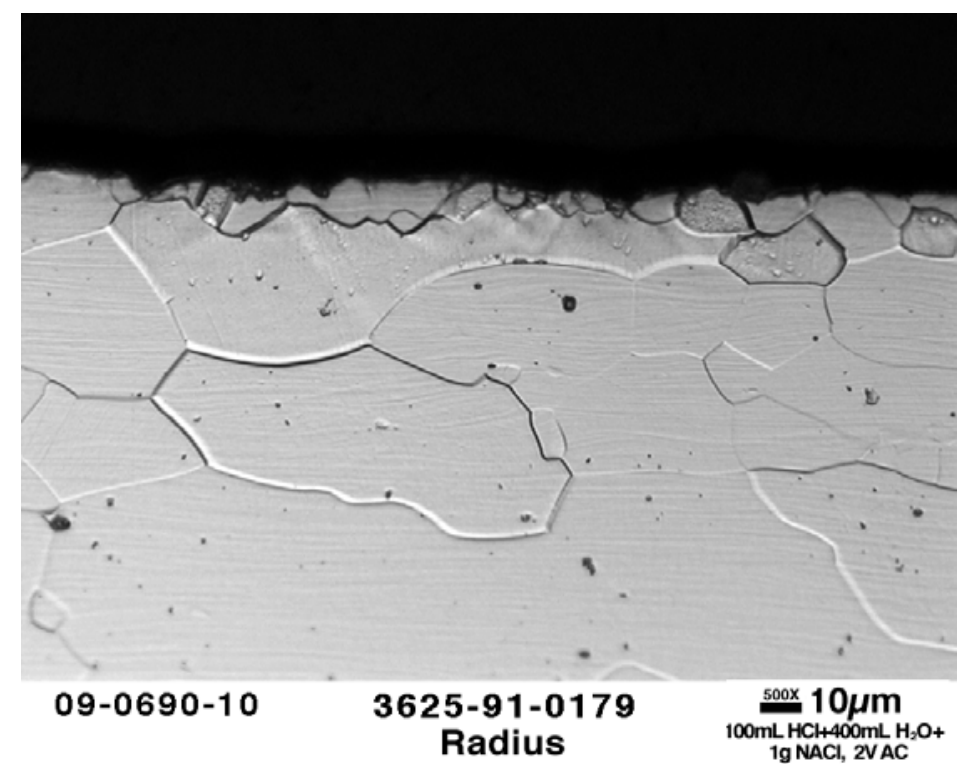

Fig. 6. Photomicrograph at 500X magnification showing fine-grained outside (upper) surface vs. the overall grain size for an iridium alloy cup sample in the recrystallized, grit blasted, air burn-off, and vacuum outgassed condition.

Table 3 summarizes the overall or bulk results for the same samples/condition in Table 2. Comparing the inside surface results in Table 2 to the overall results in Table 3 and/or the overall results in Table 1 indicates that the grain sizes are slightly finer at the inside surfaces, i.e. ASTM grain size numbers of approximately 7 versus 6 . This may be a free surface effect, i.e. grains restrained or limited by the free surface, resulting in slightly finer grains. Or there is the possibility that the apparent slight grain size difference between the inside surface and the overall structure is more related to the difficulty in judging grain size near a surface, i.e. there is little or no difference. The overall microhardnesses after the additional vacuum outgassing in Table 3 are approximately $20 \mathrm{HV}$ lower than those after the recrystallization/grit blast operations (shown in Table 1). Most likely cup processing operations (see Fig. 2) after the recrystallization operation through the grit blasting/rework operations, particularly cold sizing, impart a small amount of cold work throughout the overall microstructure. This lightly cold worked condition is typically below any critical deformation level $(<2.5 \%)$ for recrystallization or abnormal grain growth in the bulk structure. ${ }^{1-7}$ Thus, the $1250^{\circ} \mathrm{C}$ vacuum outgassing operation serves as a stress relief anneal (recovery only) yielding a lower microhardness for the bulk structure. Note: The ORNL metallography procedure, MET-MetL-QA-2, requires that the microhardness indentations be properly spaced to avoid edge and indentation interactions. Additional tabulations were made to verify that no biases (from improper spacing or any other cause) existed for the three indentations made at each pole, radius, and equator position. Also the overall grain sizes and microhardnesses in Table 3 at the equator in the grit blasted and non-grit blasted regions indicate that grit blasting has little or no effect on the overall/bulk features. 
Table 3. Metallurgical Summary for Overall (Bulk Portion of) Samples in the Recrystallized, Grit Blasted, Air Burn-off, and Vacuum Outgassed Condition (Used Witness Specimens-Similar to CVS Assembly)

Overall ASTM Grain Size Number

\begin{tabular}{cccc}
\hline Pole & Radius & Equator & $\begin{array}{c}\text { Equator non- } \\
\text { grit blast region }\end{array}$ \\
\hline 6.6 & 6.4 & 6.3 & 6.1 \\
0.3 & 0.3 & 0.3 & 0.5 \\
5 & 5 & 5 & 8 \\
6.5 & 6.0 & 6.0 & 5.5 \\
7.0 & 6.5 & 6.5 & 6.5 \\
0.5 & 0.5 & 0.5 & 1.0 \\
\hline
\end{tabular}

Overall Microhardness (HV 1000 gf)

\begin{tabular}{cccc}
\hline Pole & Radius & Equator & $\begin{array}{c}\text { Equator non-grit } \\
\text { blast region }\end{array}$ \\
\hline 225 & 233 & 223 & 215 \\
10 & 2 & 2 & 2 \\
4 & 1 & 1 & 1 \\
241 & 235 & 225 & 218 \\
218 & 230 & 221 & 213 \\
23 & 5 & 4 & 5 \\
\hline
\end{tabular}

\subsection{RECRYSTALLIZED, GRIT BLASTED, AIR BURN-OFF, VACUUM OUTGASSED AND SUBSEQUENT HEAT TREATMENT CONDITIONS}

Five used witness specimens (recrystallized, grit blasted, air burn-off, and vacuum outgassed condition) were subsequently given a final heat treatment at $1375^{\circ} \mathrm{C} / 1 \mathrm{~h}, 1500^{\circ} \mathrm{C} / 1 \mathrm{~h}, 1500^{\circ} \mathrm{C} / 70 \mathrm{~h}$, $1900^{\circ} \mathrm{C} / 1 \mathrm{~min}$, or $1900^{\circ} \mathrm{C} / 2 \mathrm{~h}$ to see if abnormal grain growth would occur via secondary recrystallization. ${ }^{1,2}$ The final heat treatment at $1375^{\circ} \mathrm{C} / 1 \mathrm{~h}$ clearly retained the finer outside surface grains as shown in Table 4 and Figs. 7 and 8 . The sample with the final heat treatment at $1500^{\circ} \mathrm{C} / 1 \mathrm{~h}$ retained some fine grains at the surface (polar location in Table 4 and Fig. 9), but many of the grains had sizes similar to the inside surface grains and the overall structure (Fig. 10 and Table 4). Table 5 shows that even though the grain sizes coarsened (ASTM grain size numbers and grains per thickness decreased) as the final heat treatment temperatures and/or times increased, the microhardnesses remained uniform. This indicates that the $1375^{\circ} \mathrm{C} / 1 \mathrm{~h}$ recrystallization operation is a full anneal. Note: The microhardnesses in Table 1 (as-recrystallized plus light cold work from subsequent processing) are slightly higher than those in Table 3 (recrystallized, lightly cold worked, stress relieved with $1250^{\circ} \mathrm{C} / 1 \mathrm{~h}$ vacuum outgas) and Table 5 as expected. The final heat treatments at $1500^{\circ} \mathrm{C} / 70 \mathrm{~h}, 1900^{\circ} \mathrm{C} / 1 \mathrm{~min}$, and $1900^{\circ} \mathrm{C} / 2 \mathrm{~h}$ generally showed uniform grain sizes between the outside and inside surfaces within each sample (Figs. 11, 12 and 13 , respectively), except for some anomalous areas that will be addressed further.

Table 4. Metallurgical Summary for the Outside and Inside Surfaces of Samples Given Subsequent Final Heat Treatments after the Recrystallization, Grit Blast, Air Burn-off, and Vacuum Outgas Operations

\begin{tabular}{|c|c|c|c|c|c|c|c|}
\hline \multirow[b]{2}{*}{$\begin{array}{l}\text { Final Heat } \\
\text { Treatment }\end{array}$} & \multirow[b]{2}{*}{ Surface } & \multicolumn{3}{|c|}{ Average Grain Size Diameter $(\mu \mathrm{m})$} & \multicolumn{3}{|c|}{$\begin{array}{c}\text { Approximate ASTM } \\
\text { Grain Size Number }\end{array}$} \\
\hline & & Pole & Radius & Equator & Pole & Radius & Equator \\
\hline \multirow{2}{*}{$1375^{\circ} \mathrm{C} / 1 \mathrm{~h}$} & Outside & 5 & 12 & 11 & 12.3 & 9.9 & 10.1 \\
\hline & Inside & 19 & 29 & 25 & 8.5 & 7.3 & 7.7 \\
\hline \multirow{2}{*}{$1500^{\circ} \mathrm{C} / 1 \mathrm{~h}$} & Outside & 43 & 40 & 43 & 5.9 & 6.3 & 5.9 \\
\hline & Inside & 38 & 45 & 48 & 6.5 & 6.0 & 5.8 \\
\hline
\end{tabular}




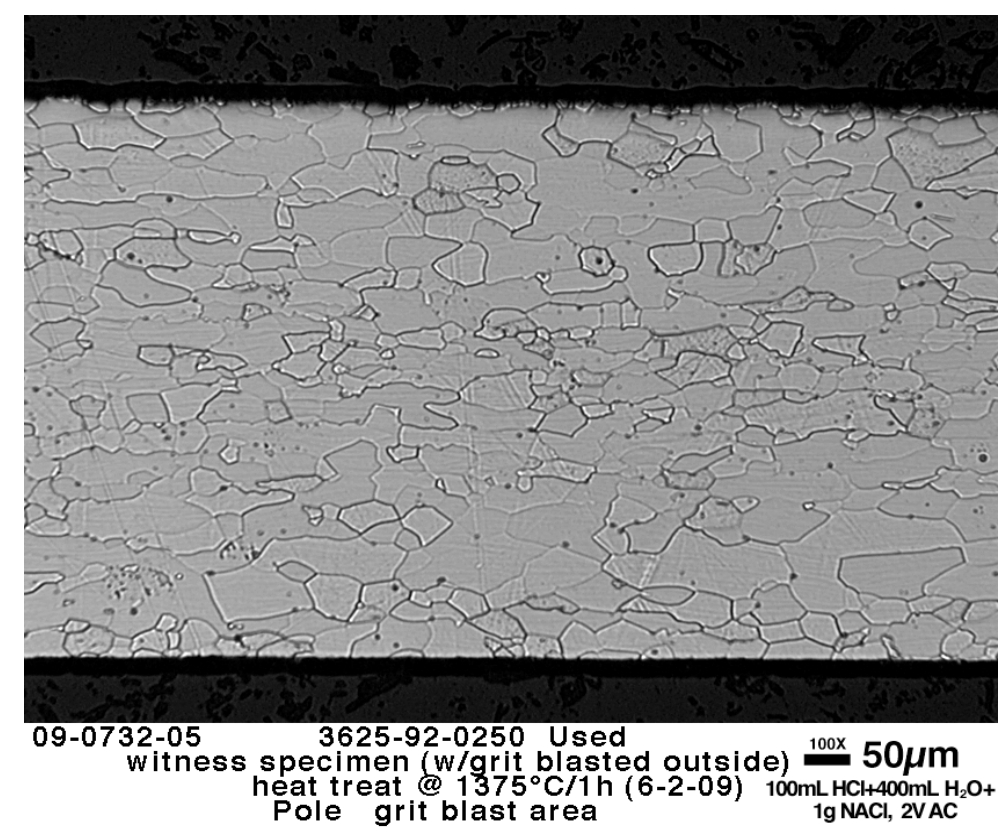

Fig. 7. Photomicrograph at $100 \mathrm{X}$ magnification showing finegrained outside (upper) surface vs. the overall grain size for a used witness specimen (recrystallized, grit blasted, air burn-off, and vacuum outgassed) and subsequently final heat treated at $1375^{\circ} \mathrm{C} / 1 \mathrm{~h}$.

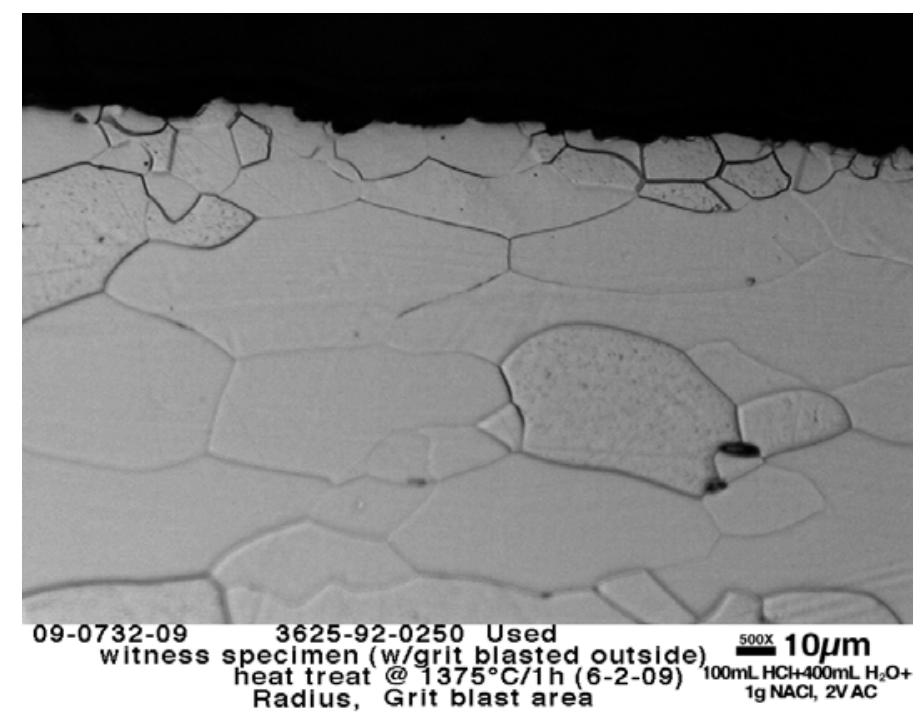

Fig. 8. Photomicrograph at 500X magnification showing fine-grained outside (upper) surface vs. the overall grain size for a used witness specimen (recrystallized, grit blasted, air burn-off, and vacuum outgassed) and subsequently final heat treated at $1375^{\circ} \mathrm{C} / 1 \mathrm{~h}$. 


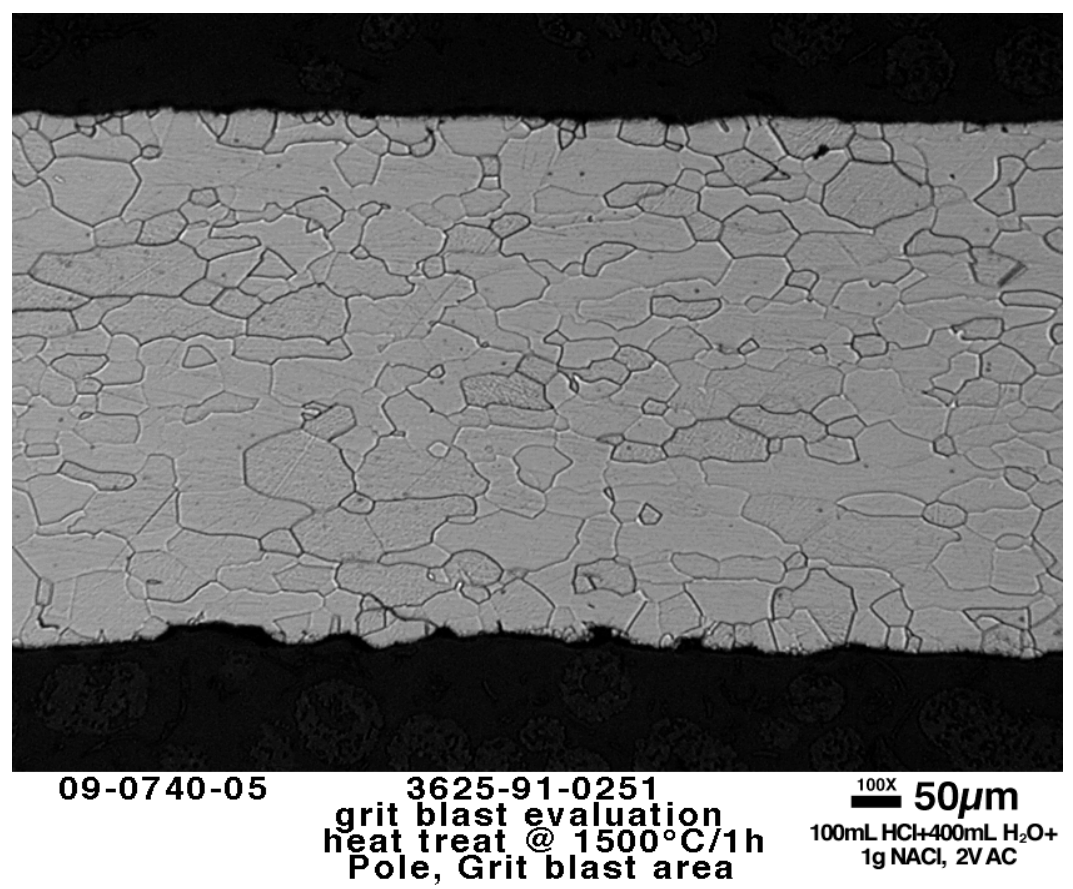

Fig. 9. Photomicrograph at 100X magnification showing fine-grained outside (upper) surface vs. the overall grain size for a used witness specimen (recrystallized, grit blasted, air burn-off, and vacuum outgassed) and subsequently final heat treated at $1500^{\circ} \mathrm{C} / 1 \mathrm{~h}$.

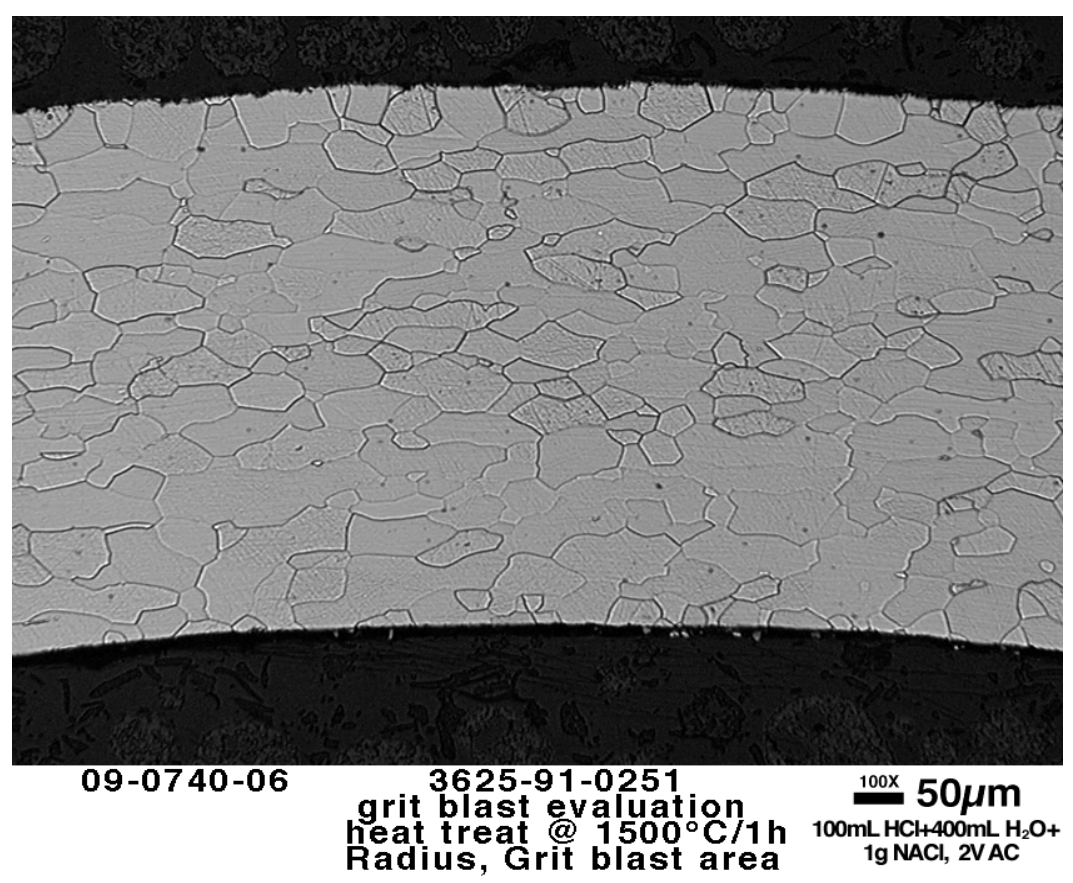

Fig. 10. Photomicrograph at $100 \mathrm{X}$ magnification showing a fairly uniform grain size on the outside (upper), inside (lower), and overall for a used witness specimen (recrystallized, grit blasted, air burn-off, and vacuum outgassed) and subsequently final heat treated at $1500^{\circ} \mathrm{C} / 1 \mathrm{~h}$. 
Table 5. Metallurgical Summary for Overall (Bulk Portion of) Samples Given Subsequent Final Heat Treatments after the Recrystallization, Grit Blast, Air Burn-off, and Vacuum Outgas Operations

\begin{tabular}{l|ccccccc} 
& \multicolumn{4}{c}{ Overall ASTM Grain Size Number } & \multicolumn{3}{c}{$\begin{array}{c}\text { Overall Microhardness } \\
\text { HV 1000 gf }\end{array}$} \\
\cline { 2 - 8 } $\begin{array}{l}\text { Final Heat } \\
\text { Treatment }\end{array}$ & Pole & Radius & Equator & $\begin{array}{c}\text { Grains Per } \\
\text { Thickness }\end{array}$ & Pole & Radius & Equator \\
\hline $1375^{\circ} \mathrm{C} / 1 \mathrm{~h}$ & 7.0 & 6.5 & 6.0 & 25 & 223 & 241 & 231 \\
$1500^{\circ} \mathrm{C} / 1 \mathrm{~h}$ & 6.5 & 6.0 & 5.5 & 19 & 259 & 236 & 228 \\
$1500^{\circ} \mathrm{C} / 70 \mathrm{~h}$ & 4.0 & 4.0 & 4.0 & 10 & 219 & 216 & 214 \\
$1900^{\circ} \mathrm{C} / 1 \mathrm{~min}$ & 2.5 & 3.0 & 2.5 & 6 & 226 & 225 & 221 \\
$1900^{\circ} \mathrm{C} / 2 \mathrm{~h}$ & 1.0 & 0.0 & 1.0 & 2 & 219 & 239 & 230 \\
\hline
\end{tabular}

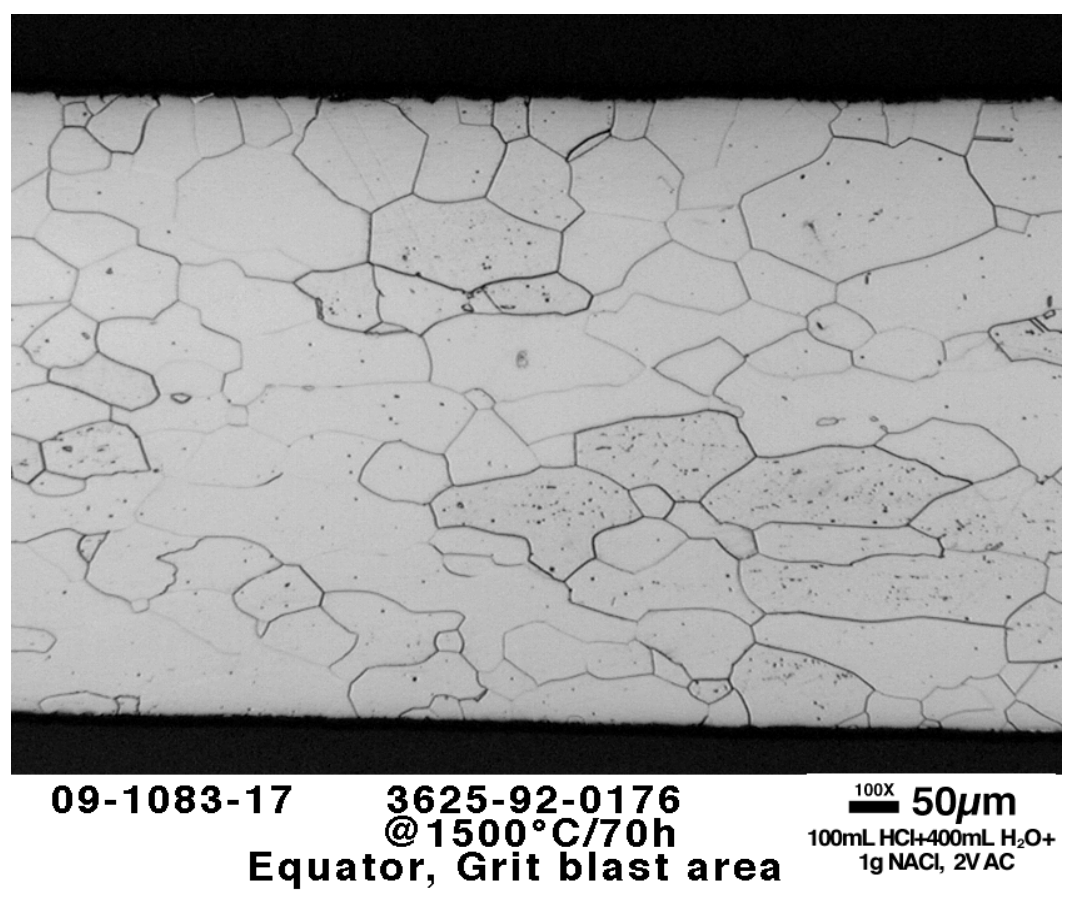

Fig. 11. Photomicrograph at $100 \mathrm{X}$ magnification showing a fairly uniform grain size on the outside (upper), inside (lower), and overall for a used witness specimen (recrystallized, grit blasted, air burn-off, and vacuum outgassed) and subsequently final heat treated at $1500^{\circ} \mathrm{C} / 70 \mathrm{~h}$. 


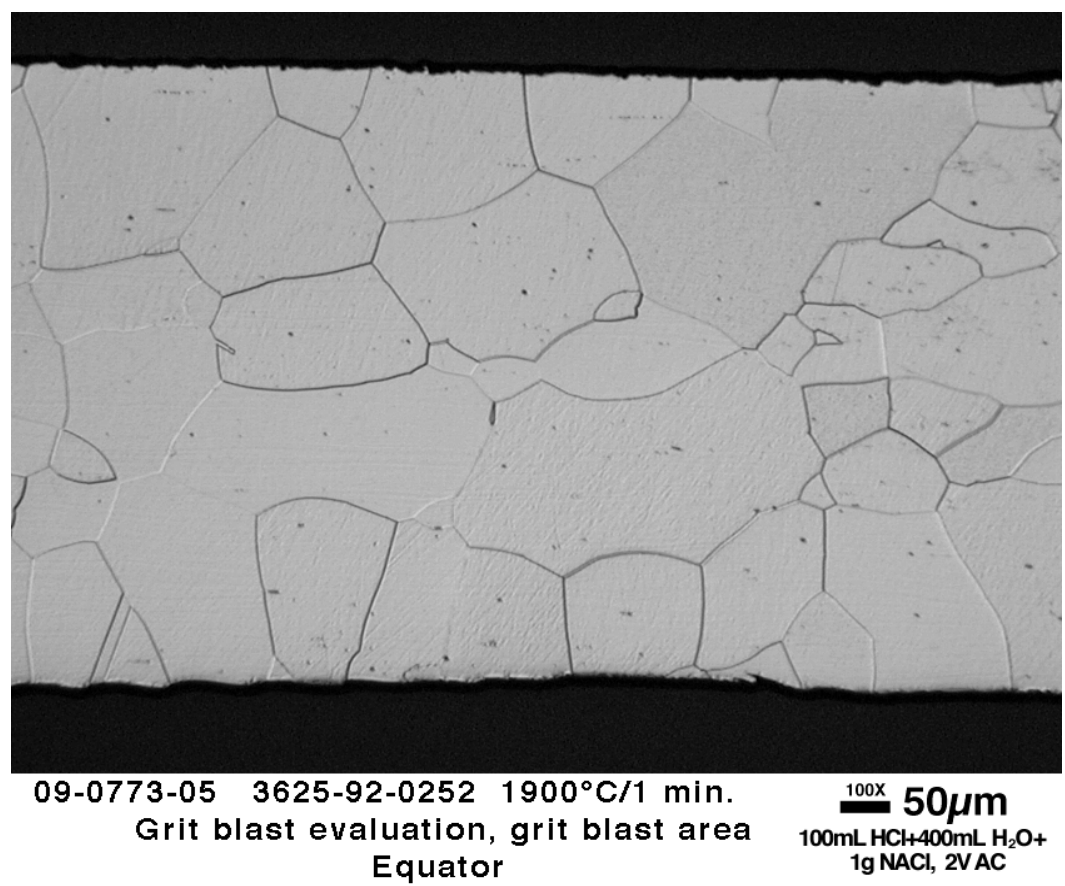

Fig. 12. Photomicrograph at $100 \mathrm{X}$ magnification showing a fairly uniform grain size on the outside (upper), inside (lower), and overall for a used witness specimen (recrystallized, grit blasted, air burn-off, and vacuum outgassed) and subsequently final heat treated at $1900^{\circ} \mathrm{C} / 1 \mathrm{~min}$.

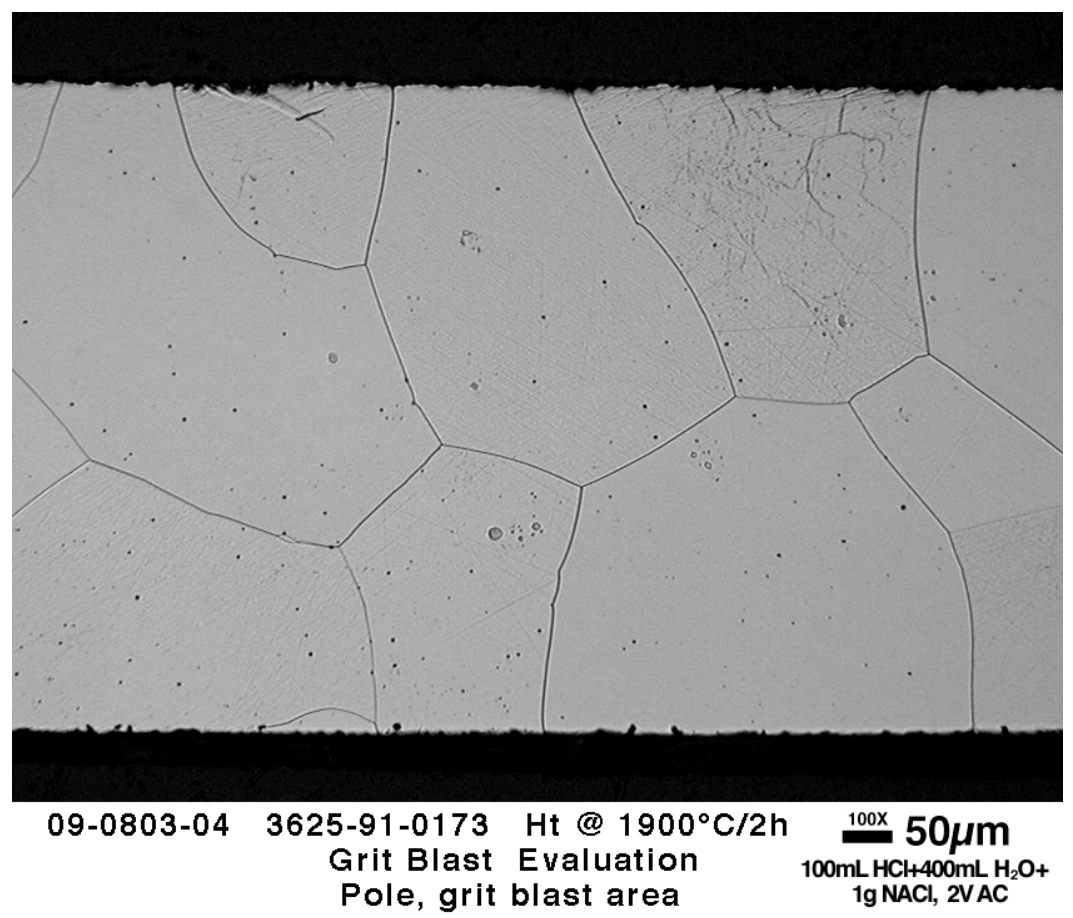

Fig. 13. Photomicrograph at $100 \mathrm{X}$ magnification showing a fairly uniform grain size on the outside (upper), inside (lower), and overall for a used witness specimen (recrystallized, grit blasted, air burn-off, and vacuum outgassed) and subsequently final heat treated at $1900^{\circ} \mathrm{C} / 2 \mathrm{~h}$. 


\subsection{ANOMALOUS CLAMPED (DURING DEBURRING) AREAS OF USED WITNESS SPECIMENS SUBSEQUENTLY GIVEN VARIOUS HEAT TREATMENTS}

Anomalous areas consisting of locally coarsened grains were found in the polar regions of some used witness specimens subsequently heat treated as described in the previous section. D-test samples (from recrystallized and grit blasted cups) were clamped for deburring during sample preparation. These samples were deburred on their edges after they were removed via EDM from the cup. The deburring operation consisted of clamping each sample in the polar region with hemostat pliers so that a hand-held motorized rotary tool could be used to remove the EDM surface from the sample edges. The clamping force must be sufficient to keep the sample from moving during deburring, but if the force is excessive it will compressively deform and/or damage the sample. If this occurs in a CVS production certification sample, the deformed/damaged area can be excluded from metallurgical analysis. A typical reduced sample thickness region from clamping with hemostat pliers and the resultant surface deformation and damage is shown in Figs. 14 and 15 for a used witness specimen (recrystallized, grit blasted, clamped, air burn-off, and vacuum outgassed).

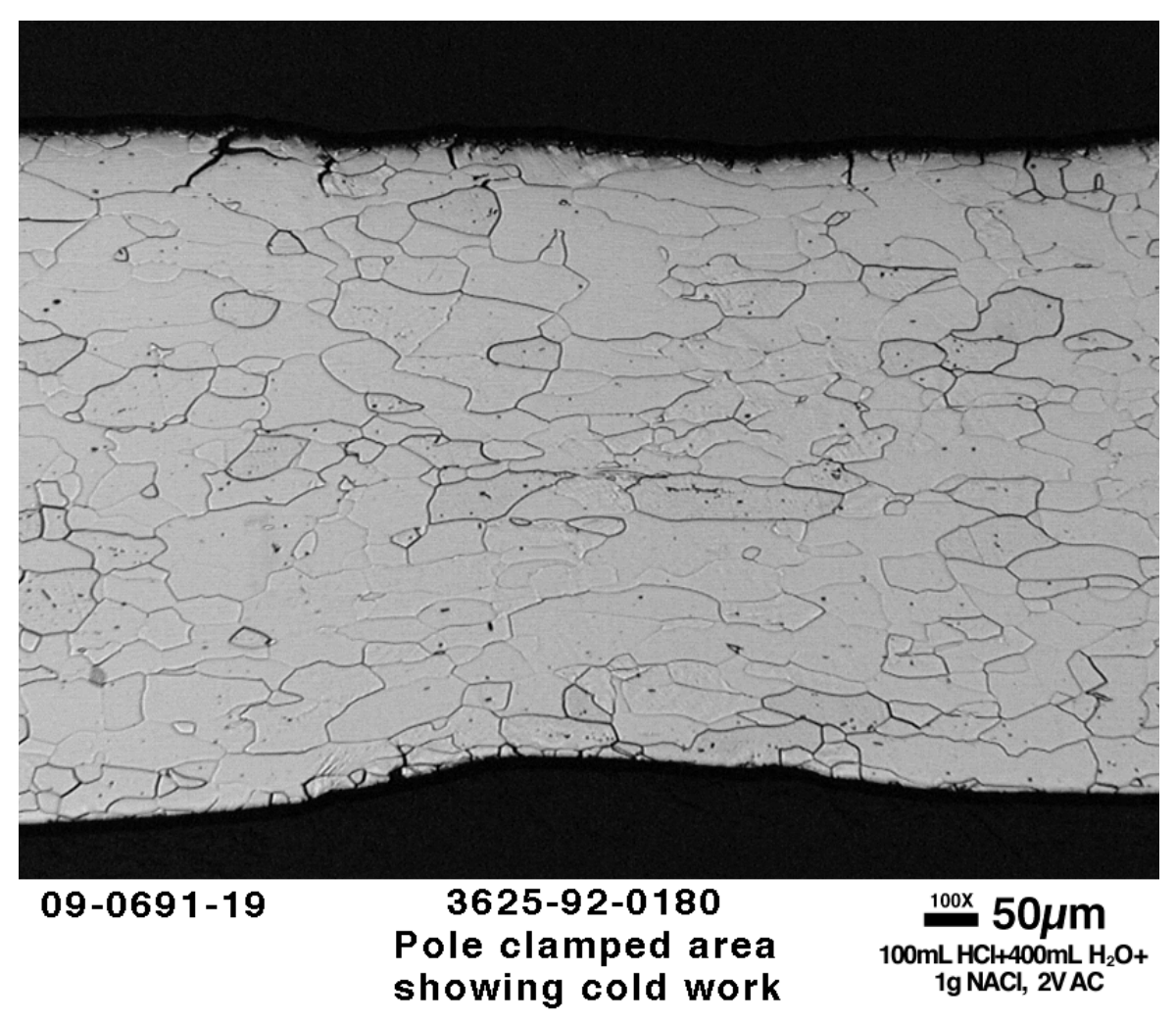

Fig. 14. Photomicrograph at $100 \mathrm{X}$ magnification showing a typical clamped area with deformation and some grain boundary separation on the outside (upper) and inside (lower) surfaces of a used witness specimen (recrystallized, grit blasted, clamped, air burn-off, and vacuum outgassed) - no grain growth. 


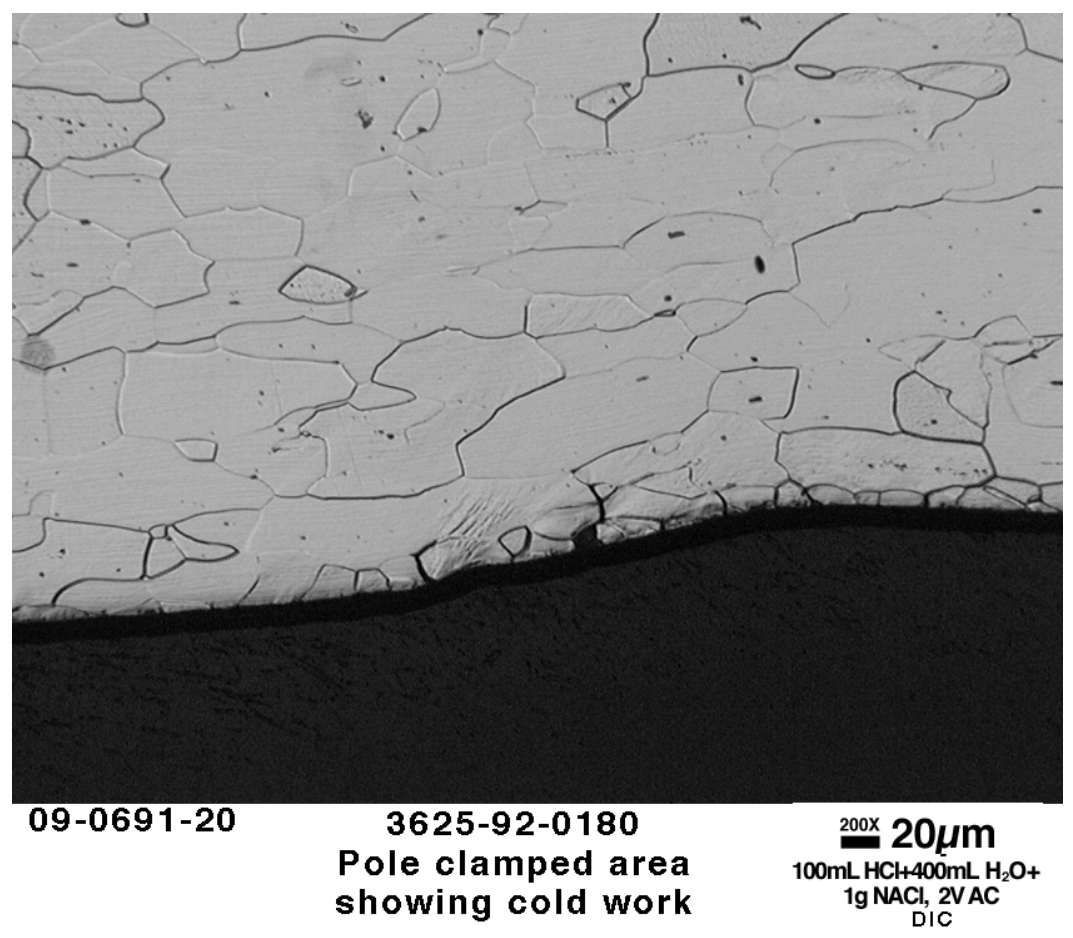

Fig. 15. Photomicrograph at 200X magnification of the clamped area on the inside (lower) surface of figure 14 clearly showing grain deformation and some grain boundary separation.

The compressive clamping forces for samples subsequently given a final heat treatment typically resulted in thickness reductions or strains of about $12 \%$ as shown in Table 6 . Also the number of grains per thickness for the clamped and non-clamped areas is shown in Table 6. No grain growth, normal or abnormal, occurred anywhere in the sample given a subsequent final heat treatment at $1375^{\circ} \mathrm{C} / 1 \mathrm{~h}$ as shown in Fig. 16. Abnormal grain growth was noted in the clamped areas of samples given subsequent final heat treatments at $1500^{\circ} \mathrm{C} / 1 \mathrm{~h}, 1500^{\circ} \mathrm{C} / 70 \mathrm{~h}$, and $1900^{\circ} \mathrm{C} / 2 \mathrm{~h}$ as shown in Figs. $17-19$, respectively. This is reinforced in Table 6 this by showing the reduced number of grains per thickness in the clamped versus the non-clamped areas of these samples. The abnormal grain growth is readily discernible in Fig. 17. Very large grains are evident in Figs. 18 and 19 which should be compared to Figs. 11 and 13, respectively, to see the true extent of the abnormal grain growth. The sample heat treated at $1900^{\circ} \mathrm{C} / 1$ min was not clamped excessively during sample deburring; therefore, no abnormal grain growth was noted.

Table 6. Clamping Strain and Number of Grains Through the Thickness in Deformed Regions of Final Heat Treatment (after the Recrystallization, Grit Blast, Air Burn-off, and Vacuum Outgas Operations) Samples

Final Heat Clamping Strain Treatment

$$
\text { (\% Reduction in Thickness) }
$$

Grains Per Thickness in Clamped Area
Grains Per Thickness in NonClamped Area

\begin{tabular}{l|ccc}
\hline & & & \\
$1375^{\circ} \mathrm{C} / 1 \mathrm{~h}$ & 10 & 25 & 25 \\
$1500^{\circ} \mathrm{C} / 1 \mathrm{~h}$ & 13 & 10 & 19 \\
$1500^{\circ} \mathrm{C} / 70 \mathrm{~h}$ & 11 & 4 & 10 \\
$1900^{\circ} \mathrm{C} / 1 \mathrm{~min}$ & None & -- & 6 \\
$1900^{\circ} \mathrm{C} / 2 \mathrm{~h}$ & 14 & 1 & 2 \\
\hline
\end{tabular}




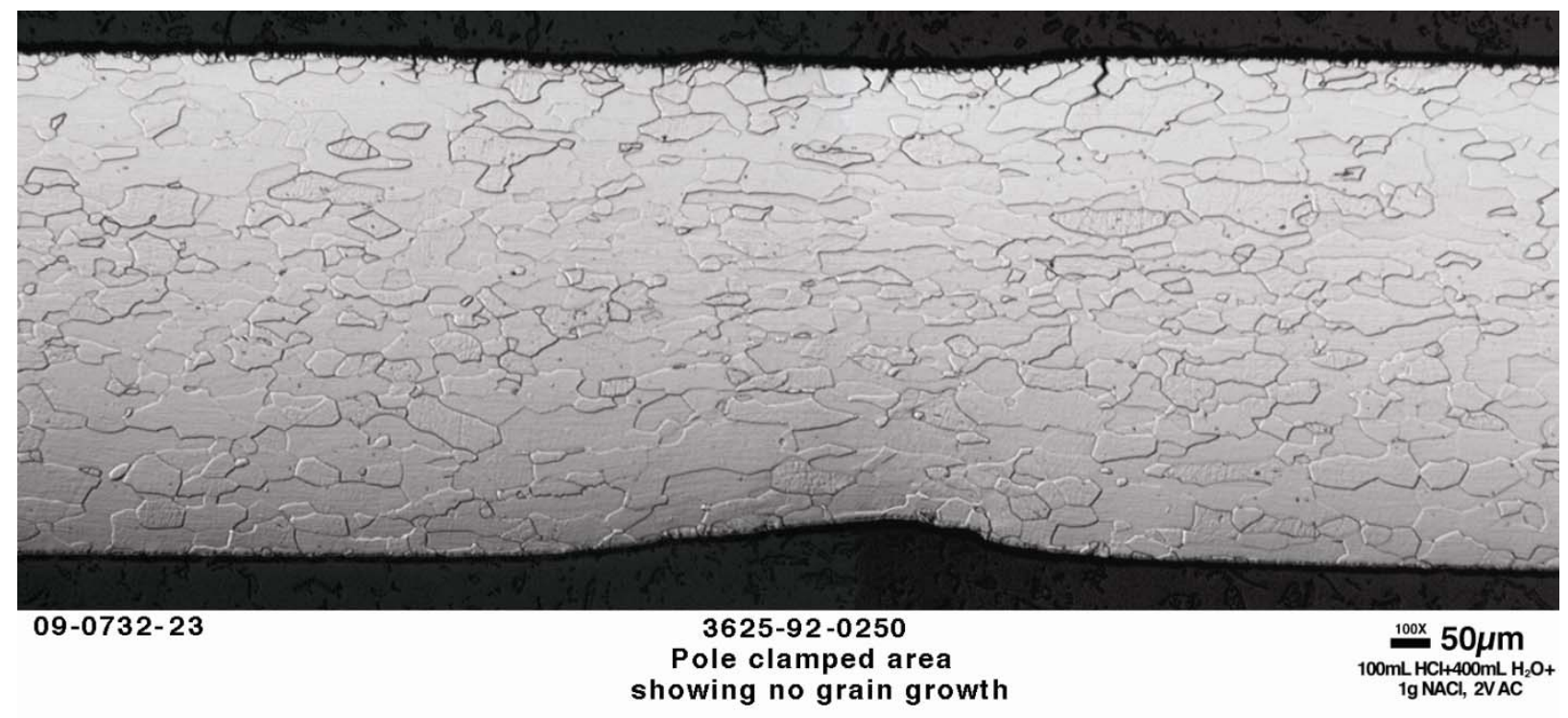

Fig. 16. Photomicrograph at $100 \mathrm{X}$ magnification showing the clamped area of the sample heat treated at $1375^{\circ} \mathrm{C} / 1 \mathrm{~h}$ after recrystallization, grit blast, clamping, air burn-off, and vacuum outgas. Some grain boundary separation is evident on the outside (upper) surface, but no grain growth has occurred.

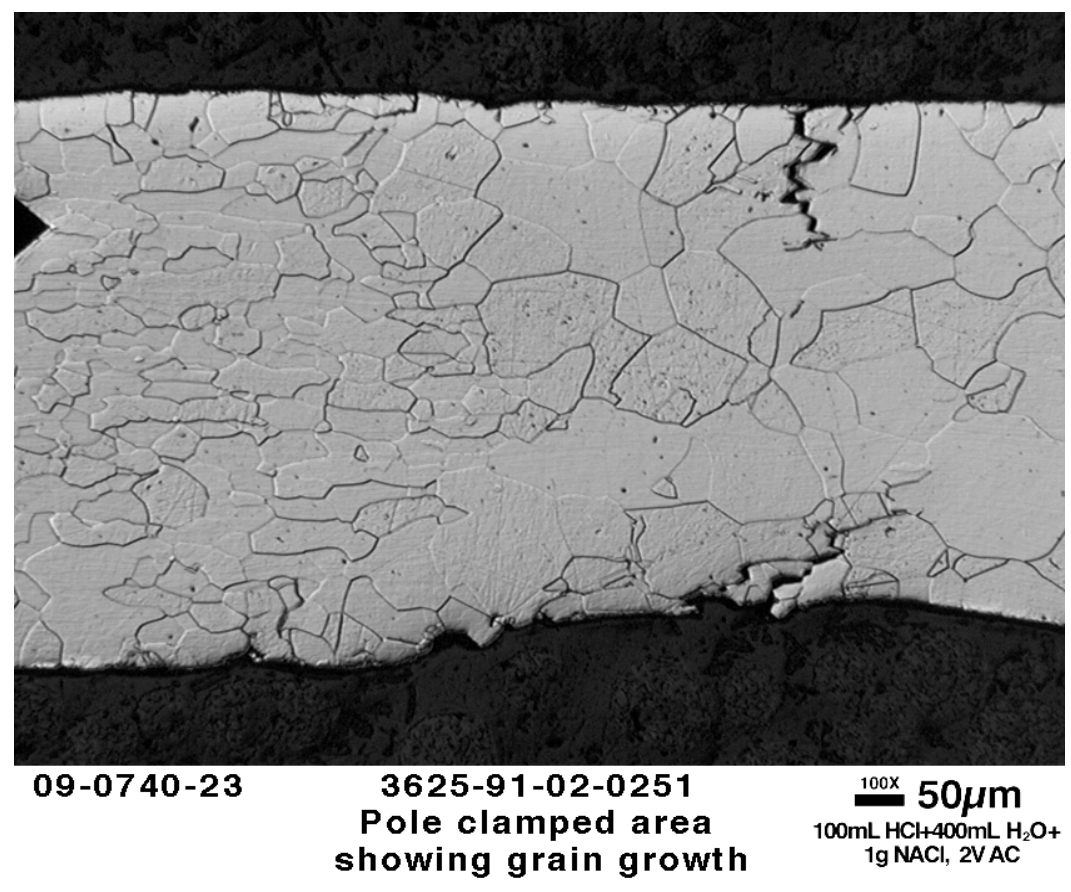

Fig. 17. Photomicrograph at 100X magnification showing the clamped area of the sample heat treated at $1500^{\circ} \mathrm{C} / 1 \mathrm{~h}$ after recrystallization, grit blast, clamping, air burn-off, and vacuum outgas. Reduced thickness and grain boundary separation are evident as well as grain growth. 


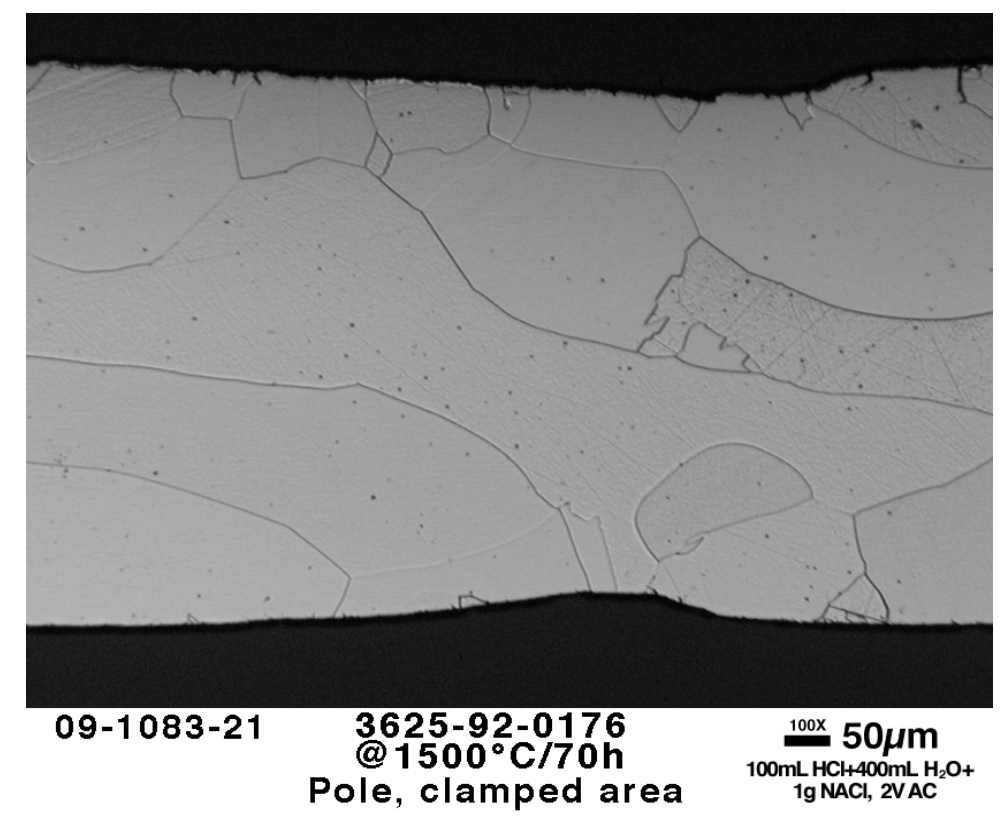

Fig. 18. Photomicrograph at $100 \mathrm{X}$ magnification showing the clamped area of the sample heat treated at $1500^{\circ} \mathrm{C} / 70 \mathrm{~h}$ after recrystallization, grit blast, clamping, air burn-off, and vacuum outgas. Reduced thickness and some grain boundary separation are evident as well as enlarged grains. Compare to figure 11 for abnormal grain growth.

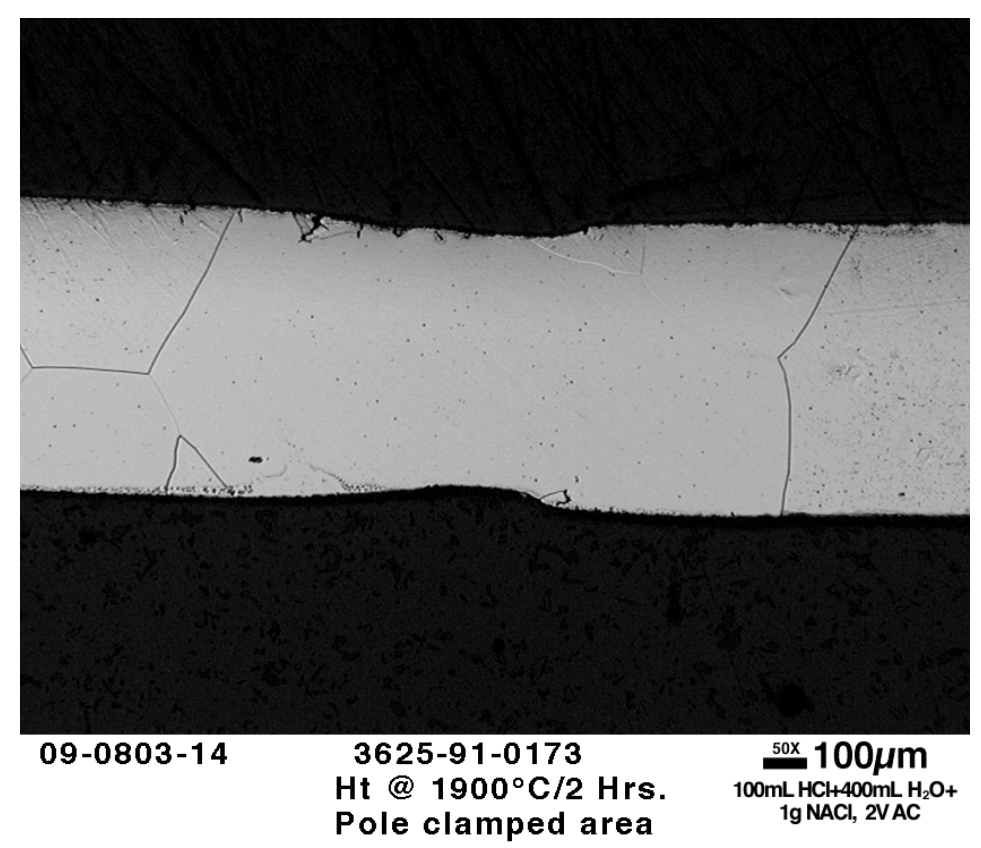

Fig. 19. Photomicrograph at 100X magnification showing the clamped area of the sample heat treated at $1900^{\circ} \mathrm{C} / 2 \mathrm{~h}$ after recrystallization, grit blast, clamping, air burn-off, and vacuum outgas. Reduced thickness and some grain boundary (former) separation are evident as well as the single grain in this area. Compare to figure 13 for abnormal grain growth. 


\subsection{COMPARISON OF CVS CUP PRODUCTION METALLURGICAL RESULTS BEFORE AND AFTER GRIT BLASTING}

Table 7 shows production destructive test results for iridium alloy cups tested for the years 1999 through 2009. This summary separates cups sampled and tested after ( 9 cups) and before ( 28 cups) the grit blasting operation. The results indicate that the overall (bulk - not surface) grain sizes and microhardnesses are similar whether the cups are sampled after or before grit blasting. The slightly larger ranges for grain sizes and microhardnesses of cups sampled before grit blasting are most likely related to the larger (3X) sample size.

Table 7. Metallurgical Summary for Iridium Alloy CVS Cup Production Destructive Test Results for the Years 1999 - 2009

\begin{tabular}{|c|c|c|c|c|c|c|}
\hline \multirow[b]{2}{*}{ Statistic } & \multicolumn{3}{|c|}{$\begin{array}{c}\text { Overall ASTM } \\
\text { Grain Size Number }\end{array}$} & \multicolumn{3}{|c|}{$\begin{array}{c}\text { Overall Microhardness } \\
\text { (HV } 1000 \mathrm{gf})\end{array}$} \\
\hline & Pole & Radius & Equator & Pole & Radius & Equator \\
\hline & \multicolumn{6}{|c|}{ Sampled Before Grit Blast Operation (9 cups) } \\
\hline Av & 6.3 & 6.3 & 6.2 & 237 & 258 & 243 \\
\hline D & 0.5 & 0.4 & 0.4 & 9 & 12 & 11 \\
\hline RSD (\%) & 8 & 6 & 6 & 4 & 5 & 5 \\
\hline Max & 5.5 & 5.5 & 5.5 & 265 & 275 & 264 \\
\hline Min & 7.5 & 7.5 & 7.0 & 222 & 230 & 225 \\
\hline \multirow[t]{2}{*}{ Range } & 2.0 & 2.0 & 1.5 & 43 & 45 & 39 \\
\hline & \multicolumn{6}{|c|}{ Sampled Before Grit Blast Operation (28 cups) } \\
\hline $\mathbf{v}$ & 6.4 & 6.5 & 6.3 & 240 & 250 & 246 \\
\hline SD & 0.5 & 0.5 & 0.5 & 13 & 11 & 11 \\
\hline RSD (\%) & 8 & 8 & 8 & 5 & 4 & 4 \\
\hline Max & 5.5 & 5.0 & 5.0 & 290 & 287 & 275 \\
\hline Min & 7.5 & 8.0 & 8.0 & 220 & 229 & 224 \\
\hline Range & 2.0 & 3.0 & 3.0 & 70 & 58 & 51 \\
\hline
\end{tabular}




\section{CONCLUSIONS}

1. The CVS cup grit blasting operation imparts cold work on the outside cup surface that ranges from 11 to $36 \mu \mathrm{m}$ deep with an average depth of $19 \mu \mathrm{m}$.

2. The $1250^{\circ} \mathrm{C} / 1 \mathrm{~h}$ vacuum outgassing operation recrystallizes the grit blasted surface to a fine grain size of approximately $9 \mu \mathrm{m}$ diameter (ASTM grain size number 11) and it serves as a stress relief anneal for the bulk structure.

3. The $1375^{\circ} \mathrm{C} / 1 \mathrm{~h}$ recrystallization operation is a full anneal.

4. Abnormal grain growth does not occur in "standard-processed" CVS cup material with heat treatments up to $1900^{\circ} \mathrm{C} / 2 \mathrm{~h}$.

5. Abnormal grain growth does occur in areas with compressive strains of $10 \%$ after heat treatment as low as $1500^{\circ} \mathrm{C} / 1 \mathrm{~h}$.

6. CVS cup production grain size and microhardness results are similar whether sampling is after or before grit blasting.

\section{REFERENCES}

1. R. Abbaschian, L. Abbaschian, and R. E. Reed-Hill, pp. 216-257 in Physical Metallurgy Principles, $4^{\text {th }}$ Edition, Cengage Learning, U.S.A, 1994.

2. R. E. Smallman and R. J. Bishop, p. 243 in Modern Physical Metallurgy and Materials Engineering, $6^{\text {th }}$ edition, Butterworth Heinemann a division of Reed Educational and Professional Publishing Ltd., 1999.

3. C. G. McKamey, E. H. Lee, G. B. Ulrich, J. L. Wright, and E. P. George, Grain Growth Behavior of DOP-26 Iridium Clad Vent Set Cups Used in Radioisotope Thermoelectric Generators, ORNL/TM2002/15, Oak Ridge National Laboratory, Oak Ridge, TN, 2002.

4. E. K. Ohriner, A. S. Sabau, and G. B. Ulrich, Plastic Straining of Iridium Alloy DOP-26 During Sizing Cup Operations, ORNL/TM-2007/169, Oak Ridge National Laboratory, Oak Ridge, TN, 2007.

5. G. Riontino, C. Antonione, L. Battezzati, F. Marino, and M. C. Tabasso, Journal of Materials Science, 14, pp. 86-90, 1979.

6. V. Randle and A. Brown, Philosophical Magazine A, Vol. 58, No. 5, pp. 717-736, 1988.

7. J. B. Koo, D. Y. Yoon, and M. F. Henry, Metallurgical and Materials Transactions A, 33A, pp. 3803-3815, December 2002. 



\section{INTERNAL DISTRIBUTION}

1. E. P. George

2-3. J. F. King

4-5. H. F. Longmire

6. R. G. Miller
7. E. K. Ohriner

8-9. G. B. Ulrich

10. ORNL Office of Technical Information and Classification

\section{EXTERNAL DISTRIBUTION}

11. R. T. Carpenter, Orbital Sciences Corporation, 20030 Century Boulevard, Suite 102, Germantown, MD 20874

12. S. Johnson, Idaho National Laboratory, P. O. Box 1625, Idaho Falls, ID 83415-6122

13. E. A. Skrabek, Orbital Sciences Corporation, 20030 Century Boulevard, Suite 102, Germantown, MD 20874

14. C. E. Van Pelt, Los Alamos National Laboratory, P. O. Box 1663, Los Alamos, NM 87545

15. Won S. Yoon, U.S. Department of Energy, 1000 Independence Avenue, SW, Germantown Building, Washington, DC 20585-1290 